\title{
Entre altares y escritorios. Liderazgo étnico y poder local en la pluma de tres curas-cronistas del Lago Titicaca (1570-1650)
}

Ariel J. Morrone*

Fecha de recepción: 11 de mayo de 2018. Fecha de aceptación: 24 de noviembre de 2018

\begin{abstract}
Resumen
El dominio colonial en los Andes meridionales a fines del siglo XVI incluyó un proceso de reducción de los colectivos étnicos a pueblos de indios y una profundización de la conversión religiosa a cargo de los curas doctrineros. Las transformaciones de los grupos nativos durante 1570-1650 habilitaron nuevos márgenes de acción para tres actores sociales que configuraron nudos de poder local: el corregidor, el cacique y el cura. Para escudriñar las interacciones entre estas autoridades en los pueblos englobados en los corregimientos adyacentes al lago Titicaca abordamos algunos discursos elaborados por religiosos sobre sus caciques contemporáneos, como los de fray Martín de Murúa, fray Alonso Ramos Gavilán y el licenciado Pedro Vallejo de Velasco, quienes ejercieron sus oficios en los pueblos de Capachica (corregimiento de Paucarcolla), Copacabana (corregimiento de Omasuyos) y Caquiaviri (corregimiento de Pacajes) respectivamente, durante las últimas décadas del siglo XVI y la primera mitad del siglo XVII.
\end{abstract}

\section{Between altars and desks. Ethnic leadership and local power in} the pen of three priests-chroniclers of Lake Titicaca (1570-1650)

\footnotetext{
Abstract

By late sixteenth century colonial rule in Southern Andes included processes of reduction of ethnic groups to pueblos de indios (native villages) and an increase of the religious conversion by parish priests (curas doctrineros). The transformations among the native groups in 1570-1650 enabled new margins of action for three social actors that became knots of local power: the provincial governor (corregidor), the ethnic leader (cacique) and the priest. To examine

\section{Palabras clave}

liderazgo étnico poder local caciques curas doctrineros
Keywords

ethnic leadership local power caciques parish priests 
the interactions between these authorities in the pueblos belonging to the corregimientos of Lake Titicaca we analyze some discourses elaborated by religious about their contemporary caciques: such as Fray Martín de Murúa, Fray Alonso Ramos Gavilán and Licenciado Pedro Vallejo de Velasco, whose offices where in the pueblos of Capachica (corregimiento of Paucarcolla), Copacabana (corregimiento of Omasuyos) and Caquiaviri (corregimiento of Pacajes), respectively, during the last decades of the sixteenth century and the first half of the seventeenth century.

\section{Introducción}

La misa había concluido. Tras despedir al último de sus feligreses y ordenar los implementos utilizados durante el oficio, fray Martín de Murúa, fray Alonso Ramos Gavilán y el Licenciado Pedro Vallejo de Velasco, cada uno en su tiempo y en sus respectivos escritorios, tomaron sus plumas para continuar el proyecto que, días atrás, habían decidido iniciar. En los trazos de sus pulcras caligrafías quedarían escritas sendas narrativas sobre la época que les tocó vivir, la historia que quisieron elaborar $\mathrm{y}$, más precisamente, instantáneas sobre las figuras de autoridad nativa del mundo andino -kuraka, mallku o, en términos generales, "caciques"- con las que interactuaron durante sus labores evangelizadoras.

El objetivo central de este artículo es rastrear cuáles fueron las representaciones y discursos elaborados por esos tres religiosos sobre los caciques andinocoloniales que fueron sus contemporáneos. Particularmente, indagamos las crónicas de fray Martín de Murúa (OM), cura de San Salvador de Capachica (corregimiento de Paucarcolla), y de fray Alonso Ramos Gavilán (OSA), cura de Nuestra Señora de Copacabana (corregimiento de Omasuyos), además un informe labrado por el Licenciado Pedro Vallejo de Velasco, cura de la Concepción de la Nueva Toledo de Caquiaviri (corregimiento de Pacajes), instrumentos elaborados entre 1590 y 1645 (ver Figura 1).

En tanto las convicciones culturales, el origen y la experiencia de cada autor determinaron las condiciones sociales de producción de sus relatos, sus obras funcionan como espejos que devuelven reflejos sesgados de los procesos descriptos (Matute, 1997). ${ }^{1}$ De esta manera, durante la fragua de sus manuscritos los autores produjeron discursos sobre los líderes étnicos y sobre su lugar en la sociedad virreinal desde sus propias perspectivas, actuando como verdaderos "etnógrafos coloniales" (Solodkow, 2014: 17-27; Morong Reyes, 2016: 45-47). Nuestra intención es interpelar las obras de Murúa, Ramos Gavilán y Vallejo de Velasco religiosos que, a más de oficiar como curas doctrineros en pueblos de reducción de la cuenca del lago Titicaca, produjeron sendas narrativas sobre sus respectivas coordenadas sociohistóricas. En esta operación, exploramos las obras tras los pasos de los caciques con los cuales estos curas-cronistas interactuaron, a partir de escudriñar la lógica interna de cada pieza y de disparar líneas de fuga hacia otra documentación y temáticas asociadas.

Nos interesa explorar el registro que los curas-cronistas dejaron sobre el panorama político local y sobre el accionar de los caciques, en un ejercicio de aproximación a temáticas más profundas tales como los repertorios discursivos disponibles para tematizar el liderazgo étnico y el impacto de esos discursos en las trayectorias políticas de curas y caciques. Los interrogantes serían: ¿cómo se relacionaron estos curas-cronistas con los caciques de sus pueblos?, ¿qué visión decían tener sobre ellos? En suma, barajamos las historias de estos curascronistas para echar luz sobre las formas específicas en que se construyó el 


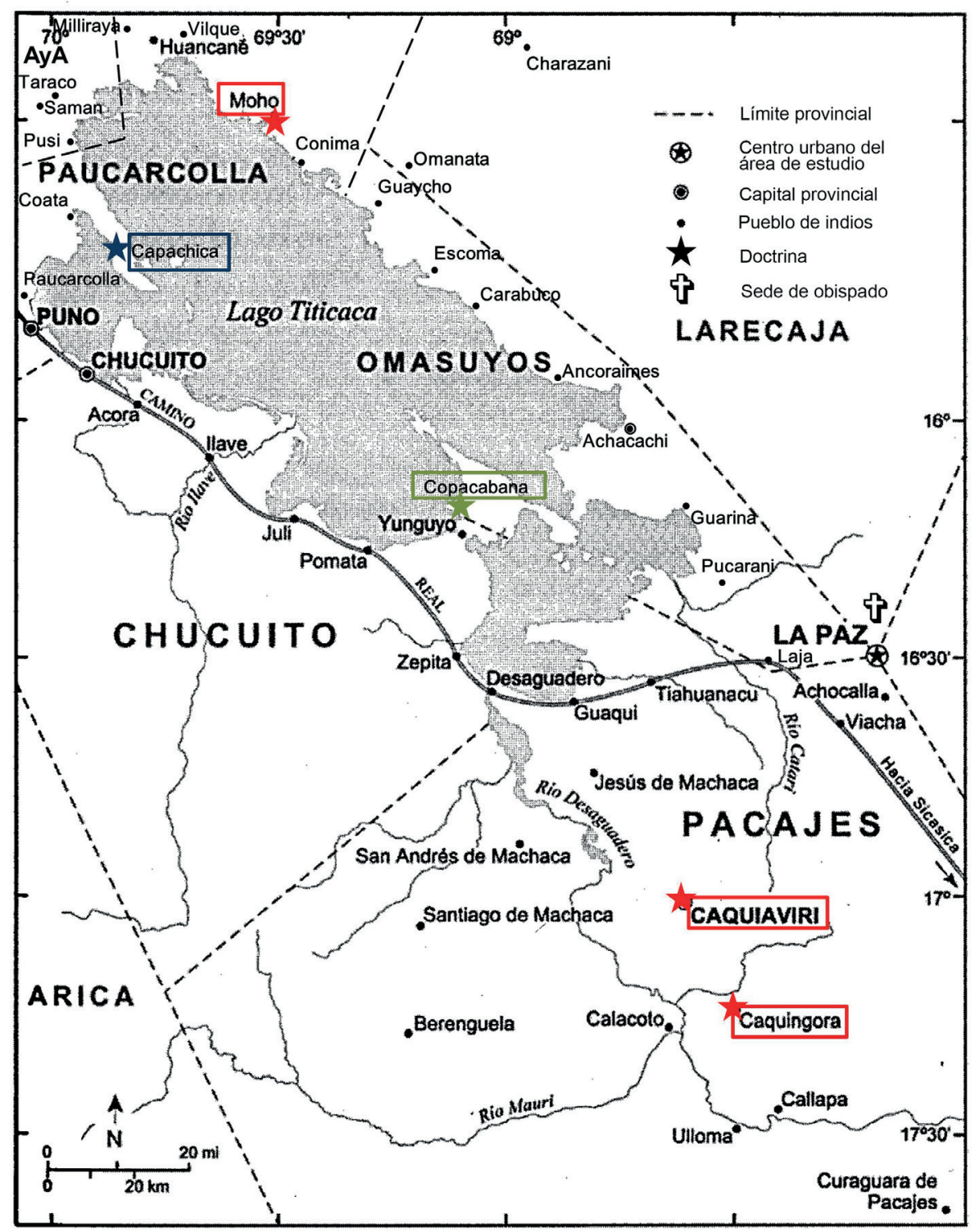

Figura 1. Pueblos de reducción del lago Titicaca, en cuyas doctrinas oficiaron los curas-cronistas abordados en el artículo: fray Martín de Murúa -azul-, fray Alonso Ramos Gavilán -verde- y Lic. Pedro Vallejo de Velasco -rojo. Intervención personal a partir de Thomson (2006: 21).

poder a escala local y sobre las redes de intermediación política que hicieron posible la reproducción del dominio colonial en la cuenca del lago Titicaca entre fines del siglo XVI y la primera mitad del siglo XVII (Saignes, 1987a; Morrone, 2010a, 2013a y 2017).

El proceso de reformas impulsado por el virrey don Francisco de Toledo (15691581) había intentado concentrar de manera forzosa a la población nativa del sur andino en pueblos de reducción para regularizar la tributación, la provisión de mano de obra mitaya para el abastecimiento del Cerro Rico de Potosí y la conversión de las almas siguiendo los lineamientos establecidos por el Tercer Concilio Limense (Stern, 1986). En este escenario, el progresivo descenso de la población tributaria representó uno de los principales problemas que la administración colonial tuvo que afrontar desde, por lo menos, mediados de la década de 1580. Este fenómeno obedecía a una combinación de dos factores: la profusión de malas cosechas y epidemias que diezmaron a la población nativa durante las dos últimas décadas del siglo XVI y el desarrollo 
2. Para el período 1573-1645 registramos una drástica caída de la población en los pueblos aquí trabajados, del orden del $93 \%$ para Capachica $(1295>92)$ y del $81 \%$ para Copacabana $(1036>192)$. En Caquiaviri la caída tuvo un impacto menor, aunque no menos significativo, dado que alcanzó el $56 \%(1509>664)$. Para 1573, cf. Cook 1975: 46, 51, 72 y para 1645 , cf. AGN, Buenos Aires, Sala IX, Legajos 17-1-4 y 20-4-4. Retomaremos algunas de estas variables demográficas hacia el final del trabajo.

3. Entre otros curas-cronistas del sur andino podemos mencionar a Bartolomé Álvarez, cura de la Villa Real de Aullagas (corregimiento de Paria), autor de De las Costumbres y Conversión de los Indios del Perú. (continúa en página 70).

4. Abordamos los dos manuscritos de Murúa de manera integrada. Durante la preparación de este trabajo realizamos un largo excursus entre los debates historiográficos, biobibliográficos y codicológicos que permiten reconstruir, luego de una ardua lectura, los derroteros de los manuscritos Poyanne-Loyola-Galvin (Murúa [159o] 1946) y Salamanca-Wellington-Getty ([1616] 1987), cuyas versiones facsimilares fueron editadas en 2004 y 2008, respectivamente; cf. Ballesteros Gaibrois, 1987; Ossio, 1998, 1999, 2005 y 2008; Álvarez-Calderón Gerbolini, 2004; Adorno, 2004 y 2008; Adorno y Boserup, 2005; Cummins y Ossio, 2014; Escandón, 2015. Para el análisis combinado de ambos manuscritos empleamos la tabla de conversión confeccionada por Adorno y Boserup (2008: 48-61).

5. El convento mercedario de la ciudad de La Paz, fundado en 1549 albergaba para 1599 al comendador de la orden y a seis sacerdotes ( $\mathrm{Pa}$ lacio y Brunet, 1977: 73)

6. Tal es la sugerencia de Juan Ossio $(2008: 78,93)$ en función de una reinterpretación de las crónicas de la orden mercedaria en el Perú. Esta fecha entra en contradicción con la de nacimiento propuesta por Aguinagalde Olaizola (2017) en torno a 1566, pues de ser así Murúa habría llegado a los once años al Perú, y habría tenido veinticuatro años para 1590, fecha en que el propio cronista alegaba tener treinta años. Recientemente, Ossio y Aguinagalde Olaizola han establecido contacto para dialogar sobre el tema (Ossio, 2018; Paredes Laos, 2018).

7. Las citas de pasajes específicos de cada obra siguen este formato: libro, capítulo, año de la edición consultada, páginas. Así al indicar “Il, 7, 1987: 361", nos referimos al capítulo 7 del Libro II de la edición de 1987, página 361. de un "ausentismo táctico antifiscal", práctica que consistía en el abandono de los pueblos altiplánicos sujetos a la mita y la migración y el reasentamiento en corregimientos vallunos libres de mita, estancias de españoles o núcleos urbanos (Saignes, 1987b). ${ }^{2}$

Insertamos, pues, los pareceres de los curas-cronistas en esta coyuntura de sistematización y primera crisis del "orden toledano", puntualmente en el marco de las relaciones sociales configuradas en sus respectivas doctrinas. ${ }^{3}$ Asimismo, apuntamos a "pensar la región" del lago Titicaca a través de la construcción de redes de poder, personificadas en elencos de caciques, curas y corregidores, constituyendo este artículo otro avance de investigación sobre las relaciones entabladas entre esos dos primeros ejes del poder local (Morrone, 2016 y 2017).

\section{Los caciques como piezas clave del dominio colonial: Fray Martín de Murúa}

Fray Martín de Murúa escribió dos manuscritos, la Historia del Origen y Genealogía Real de los Reyes Incas del Perú, durante la década de 1590, y la Historia General del Perú, cuya elaboración habría culminado entre 1611 y 1613. ${ }^{4} \mathrm{Su}$ redacción de una apologética "historia total" del pasado incaico, la conquista del Perú y las primeras décadas del dominio colonial estaba asociada de manera directa con los intereses de la orden mercedaria por fortalecer su posición en el campo religioso virreinal que, desde la década de 1570, se encontraba en plena reconfiguración a partir del ingreso de la Compañía de Jesús y del fortalecimiento del clero secular (Estenssoro Fuchs, 2003; Ramos, 2010). ${ }^{5}$

Murúa habría llegado al Perú hacia $1577,{ }^{6}$ luego de oficiar como cura doctrinero a principios de la década de 1580 en el pueblo de San Salvador de Capachica -corregimiento de Paucarcolla, al norte del lago Titicaca-, hacia 1585 ingresó en el convento mercedario de la ciudad del Cuzco donde iniciaría su labor como cronista hilvanando los materiales recogidos durante sus oficios con crónicas precedentes como las de Miguel Cabello Balboa o Pedro Sarmiento de Gamboa (Ossio, 2008: 78; Adorno, 2008: 116). A partir de la lectura cruzada de ambas obras de Murúa identificamos una serie de tópicos que, articulados entre sí, conforman un exhaustivo panorama sobre las figuras de liderazgo nativo, tanto para el período prehispánico como para las primeras décadas del dominio colonial. Vista a la distancia, la caracterización presentada por Murúa conforma una verdadera agenda de investigación sobre la organización política del mundo andino hasta fines del siglo XVI.

El cronista rescata la centralidad de las autoridades locales -a quienes denomina indistintamente "curacas", "señores" y "caciques"- en el entramado político-administrativo del imperio incaico, cuyo dominio había puesto orden en términos políticos, sociales, económicos y cosmológicos un caótico mundo de "behetrías" (I, 1, 1946: 47-49; II, 7, 1987: 361). ${ }^{7}$ Tanto en la conquista militar como en la construcción de alianzas políticas, el Tawantinsuyu se valió de los liderazgos preexistentes para establecer un sistema de dominio de tipo indirecto. El autor identifica grandes líderes regionales del sur andino, entre los cuales destaca a Javilla, sindicado como "Rey en el Collao [...] deste Vilcanota hasta Chile y aun más adelante" (III, 21, 1946: 214-215). Asimismo, Murúa repara en la participación de otros mallku del altiplano lacustre, como Cavana de Ylavi y a Muncu Pucara de Hatuncolla, y más tarde en Apu Cari de Chucuito, al frente de los ejércitos conquistadores del inka Wayna Capaq, fundamentalmente en sus campañas septentrionales a Guancavilcas, Quito y Pasto (I, 32-33, 1987: 
114-119). Investigaciones arqueológicas recientes sugieren que estos grandes liderazgos regionales fueron inducidos por el poder cuzqueño (Frye y de la Vega, 2005; Arkush, 2009 y 2011), cuestionando los postulados clásicos sobre las grandes jefaturas lacustres preincaicas (Murra, 1975; Bouysse-Cassagne, 1978 y 1988; Julien, [1983] 2004). Más allá de estos matices, resaltamos que Murúa identifica los principales núcleos de poder altiplánicos brindando pistas para cartografiar los esquemas de agregación política que los españoles debieron enfrentar en su avance al sur andino.

El entramado de alianzas constituyó el otro extremo del arco de estrategias adoptadas durante la expansión incaica. Al respecto, el cronista enumera detalladamente el complejo de objetos y atributos de poder entregados a los líderes que se avinieron al nuevo orden, "conforme a su calidad, y al amor que les tenía" (II, 15, 1987: 384). Así, las andas guerreras, el dúho o tiana, asiento desde donde las autoridades organizaban el mundo -social y cosmológico-, los unku -finos trajes de lana de vicuña o cumbi-, parcelas de tierra y mujeres escogidas desfilan por la obra de Murúa como expresión material de los nuevos criterios de legitimidad de los liderazgos locales (III, 5, 1946: 172-173; II, 23, 1987: 407-408). A través de la asignación de una mujer escogida -perteneciente a una panaqa cuzqueña y/o bajo la categoría de aqlla- a un kuraka aliado, el imperio legitimaba tanto su nuevo status como la descendencia habida en ella (III, 33, 1946: 243). Tal habría sido el caso de los mallku de Charcas, quienes "como duques y marqueses; [...] resplandecían, siendo como eran de la sangre real del Inga, a manera de flores" (IV, 15, 1946: 412). ${ }^{8}$ El ennoblecimiento de la descendencia incaizada determinó las pautas sucesorias de las entidades políticas anexadas al imperio: a la muerte del kuraka aliado serían los hijos habidos en esas mujeres otorgadas por el Inka quienes accederían al cargo (I, 26, 1987: 95-96), aunque de no reunir las condiciones de habilidad suficientes podían ser reemplazados por otro hijo o varón del grupo de parentesco bajo el amparo imperial (II, 14, 1987: 381).

Con respecto a la religiosidad, sostén ideológico de la legitimidad de los kuraka, Murúa presenta diferentes caracterizaciones sobre las actitudes de estas autoridades, tanto en tiempos prehispánicos como en tiempos coloniales. Por momentos, el cronista identifica directamente a los kuraka en su rol de "hechiceros", o como sus cómplices e instigadores. Los caciques solían acudir a los "hechiceros" para consultar por su suerte o la de sus seguidores, "y para esta elección preceden diversas ceremonias, ritos y ayunos que les mandan hacer los mismos Caciques o los hechiceros por su orden" (III, 59, 1946: 309). Murúa remarca la relevancia de estas figuras de liderazgo religioso-espiritual al punto de revelar que: "así en este género de hechiceros y hechiceras eran temidos en general aun hasta de los caciques" (II, 32, 1987: 433). Este temor que los "hechiceros" suscitaban entre los caciques convertía a unos y otros en colaboradores: "y también porque ellos no descubran sus bellaquerías e idolatrías que los curacas hacen, de que son cómplices y ayudantes los hechiceros, y así él está solapado y encubierto" (II, 37, 1987: 447). ${ }^{9}$

Las ceremonias oficiadas por el Tawantinsuyu para redistribuir bienes entre los líderes locales (III, 48, 1946: 276) o las que seguían a su muerte (III, 11, 1946: 189) eran instancias propicias para el consumo de bebidas fermentadas y otras sustancias psicotrópicas, prácticas que, ya en tiempos coloniales, fueron sindicadas como idolátricas. Murúa lamenta en reiterados pasajes la continuidad de estos cultos, si bien sostiene que la adoración a las waka "se ha olvidado, mas con todo no dejará de haber algún rastro, y en especial donde hay viejos y viejas y curacas principales, inclinados a estos ritos"' (I, 9, 1946: 67).
8. Este atributo de los mallku de Charcas, quienes "resplandecían [...] a manera de flores", podría asociarse con el título honoríico de janq'u tutumpi (“flor blanca que brota", en referencia al amancay o la azucena) que el inka Pachakuti le habría asignado a Tata Ayra Canchi, mallku de los qaraqara, en señal de alianza política (Platt et al., 2006: 688-691).

9. De hecho, Murúa había recibido una comisión de parte del provisor del Cuzco "para hazer aberiguación contra las echiçeras", documento hallado por su hermano Diego de Murúa Arangutia tras inventariar los bienes dejados por el religioso al morir el 6 de diciembre de 1615 (Aguinagalde Olaizola, 2017: 67). 
10. Como profundizaremos en el apartado siguiente, la península de Copacabana y las islas circundantes constituían, desde tiempos preincaicos, importantes centros de peregrinaje a escala regional (SallesReese, 1997; Bauer y Stanish, 2001; de la Vega y Stanish, 2002; Rostworowski, 2003).

11. Thérèse Bouysse-Cassagne (1988: 68, 70) sugiere la ubicación del templo solar de Guarina al noroeste del lago, en asociación a la entidad estatal Wari del Horizonte Medio. Sin embargo, en un trabajo posterior (2010: 295), identifica ese topónimo con lo que, en tiempos coloniales, sería el repartimiento -y luego pueblo de reducción- de Guarina -corregimiento de Omasuyos-, también a cargo de la orden mercedaria. Siguiendo esa premisa, es nuestra hipótesis que el santuario cristiano de Nuestra Señora de las Peñas de Guarina se construyó sobre los cimientos del antiguo santuario solar, a partir de una segunda apropiación de este espacio sacralizado. El santuario figura en las visitas de los virreyes marqués de Mancera (1645, AGN IX, 17-1-4) y duque de La Palata (1683, AGN XIII, 17-2-3). Sobre los milagros adjudicados a la imagen mariana de Nuestra Señora de las Peñas, cf. la descripción realizada en 1651 por don Antonio de Castro y del Castillo, quinto obispo de La Paz (Maurtúa, 1906, XI: 221-222 y 242).

12. En el inventario de los bienes de Murúa también consta que "en otra bolsa de lana de las yndias se hallo una camisa delgada de lana que segun dixeron pareçe fue camisa del rey ynga" (Aguinagalde Olaizola, 2017: 66).
Para mayor conocimiento de la realidad sobre la que debían operar los religiosos a cargo de la evangelización, Murúa ofrece una descripción de los principales hitos de la geografía sagrada del sur andino, cuyo eje se ubica indudablemente en el lago Titicaca, la península de Copacabana y las islas aledañas, dedicadas al culto solar incaico (II, 36, 1987: 444-445). ${ }^{10}$ El establecimiento de miembros de las panaqa cuzqueñas como suyuyoq apu ("virrey" o gobernador de suyu) en Tiwanaku (I, 26, 1987: 97) y en Copacabana, "lugar de la mayor idolatría que hubo en todo el Perú" (III, 15, 1946: 201) muestra el claro interés del poder incaico por controlar un espacio sacralizado, cuya reorientación hacia el culto solar fue clave para garantizar el sometimiento de la población local a través de mecanismos ideológicos. Además de Copacabana y las islas, Murúa registra "otra casi general Guaca hacia Guarina inteca, que es como el sol, porque Inti llaman al sol, y hay otras circunvecinas" (III, 31, 1946: 215). ${ }^{11}$

Otro componente de la geografía lacustre destacado en las obras de Murúa son los talleres de producción especializada implantados por el Tawantinsuyu. En particular, el pueblo de Capachica (reducto de habla pukina donde Murúa actuó como cura doctrinero) había sido un centro de producción textil, donde un conjunto de especialistas en el trabajo de la lana de vicuña (cumbicamayoq) junto a tejedoras aqlla elaboraban prendas de alto valor simbólico en la economía política del imperio (Murra, [1955] 1999: 117). Murúa señala que "aun hasta hoy día guardan las dichas ropas de cumbi, de las cuales, como dotrinante que he sido en el dicho pueblo de Capachica, he visto sacar algunas de ellas el día del Corpus". El cronista señala que esos textiles incaicos eran objeto de veneración por parte de los nativos:

[...] y para mayor testificación de lo que digo, tengo en mi poder una camiseta del propio Inga, que la hube en el dicho pueblo, que cabe en un puño; y aun en hartas ocasiones me [la] han querido coger para sus errores, porque es muy finísima, que no hay quien la vea que no se quede admirado y espantado (III, 21, 1946: 215-216).

Probablemente, Murúa haya obtenido -por medios no del todo consensuados, como veremos- muestras de pequeños textiles diseñados por los cumbicamayoq para adornar figurinas de oro o plata destinadas al culto solar, al ritual de la capacocha o a ajuares funerarios en santuarios de altura (Abal de Russo, 2010; Cereceda, 2014). ${ }^{12}$

Sabemos que los unku de cumbi formaban parte de la parafernalia imperial redistribuida entre los líderes locales para materializar su sometimiento y garantizar su colaboración con el orden imperial (Murra, 1975: 164-170). Al respecto, Murúa señala que el Inka obsequiaba a los kuraka "dos camisetas estampadas de oro, y otras cuatro estampadas de plata; trescientas piezas de ropa de lipi y cumbi para su vestir" (III, 5, 1946: 171-172; cf. Murra, [1955] 1999: 121). El afanoso conocimiento del cronista sobre la textilería incaica era tal que, de hecho, pudo enumerar con altísimo grado de detalle los tipos de especialización artesanal en ese rubro (III, 67, 1946: 332-334). El Tawantinsuyu explotó las riquezas ganaderas del Collao a partir de la reorganización de los rebaños, el establecimiento de pastores dedicados al cuidado del ganado imperial (los michiq, cf. III, 67, 1946: 335; Murra, 1975: 119-120) y de talleres especializados a tiempo completo en la producción textil, como los de Milliraya, Conima, el pueblo antiguo de Suana en términos de Juli, y los templos solares de Ayaviri, Hatuncolla y del lago (Spurling, 1992: 213-241; cf. Espinoza Soriano, 1987). En efecto, el taller de Capachica formó parte de este complejo 
ganadero-textil-religioso instalado por el Tawantinsuyu en el sector pukina del norte del lago Titicaca (Bouysse-Cassagne, 2010).

Para la época colonial, Murúa señala en términos generales:

Los curacas que gobiernan a los indios en la cobranza de las tasas, son los mismos que en tiempo del Ynga tuvieron el mando y señorío, y sus descendientes lo van continuando con título y merced, que para ello se les hace por el virrey. Para ello hacen sus informaciones como sus padres y abuelos fueron curacas en el tiempo de los Yngas, y así se prosigue el gobierno por los mismos que los rigieron antiguamente (III, 6, 1987: 482).

Murúa recupera aquí la identificación que la Corona castellana operó entre las figuras de liderazgo nativo y la nobleza peninsular, lo cual garantizaba a los caciques formalmente reconocidos y a sus hijos primogénitos la exención de las cargas coloniales -tributo y mita. Los atributos de mando y los derechos de recibir títulos y mercedes reales derivaban de la virtuosa ostentación del señorío, elemento clave de la legitimidad en el ordenamiento jurídico-político castellano. $^{13}$

Los caciques tuvieron un rol protagónico durante el encuentro entre Atawallpa y Francisco Pizarro en Cajamarca: Murúa menciona cómo "ciertos caciques de los más principales" llevaban en andas al inka (II, 10, 1946: 127; I, 59, 1987: 208-209). Asimismo, el cronista relata cómo seis años después, hacia 1538, Quintiraura, mallku de los pakaxa del sur del lago Titicaca, encabezó la resistencia nativa contra el avance de Hernando Pizarro al Collao (I, 71, 1978: 251-254; cf. Morrone, 2013b: 348-350). Más allá de estas menciones puntuales, poco es lo que el cronista aporta al conocimiento específico de los caciques coloniales y menos aún de los caciques del altiplano circunlacustre, aunque sí queda clara la reedición de su rol de intermediación sociopolítica.

Desconocemos quiénes fueron los informantes de Murúa durante el tiempo que ofició como cura doctrinero en Capachica. A modo de hipótesis, bien podrían haber sido algunos descendientes de los tejedores y pastores incaicos o alguna figura de autoridad local, en cuyas memorias se hallarían bastante presentes el pasado prehispánico y los impactos de la conquista. ${ }^{14}$ Si bien el cronista no hace referencia explícita a sus caciques contemporáneos, admite haber visto "a un Indio curaca y viejo tener en un cordel grande de estos todo el calendario Romano" (III, 25, 1946: 225) "y todos los santos y fiestas de guardar por sus meses distintos" (II, 11, 1987: 376). Verificamos, pues, la continuidad del oficio de khipucamayoq en tiempos coloniales, asociado a la figura del "contador" inserta en las estructuras del poder étnico (de la Puente Luna y Curatola Petrocchi, 2013). Hallamos incluso "contadores" en Capachica hasta bien entrado el siglo XVII. En un auto de fenecimiento de cuentas con su encomendero don Luis de Peralta Cabeza de Vaca de 1611, registramos a Bautista Canasa, contador de la parcialidad urcosuyo, a don Francisco Paricay, contador de Amantani, y a Pablo Guacani, contador de omasuyo. En 1645, durante la visita ordenada por el virrey marqués de Mancera, fueron asentados en el padrón don Diego Pahasaca y Pedro Yucra como contadores. ${ }^{15}$ En tanto portadores y especialistas en la interpretación de los khipu estas autoridades eran depositarios no sólo de la memoria colectiva sino también de sus soportes materiales.

Para la época en que Murúa ofició como cura doctrinero, el repartimiento de Capachica alcanzaba los 1295 tributarios sometidos al pago en plata ensayada, piezas de ropa de abasca y hechuras, chuño y pescado (Cook, 1975: 51). Tal
13."Señor es llamado propiamente aquel que a mandamiento, e poderío, sobre todos aquellos que biven en su tierra. E a este atal deven todos llamar Señor, tambien sus naturales, como los otros que vienen a el, o a su tierra" (Covarrubias, [1611] 1943: 934).

14. La tasa toledana de 1575 registra ocho autoridades étnicas en Capachica: don Carlos Copo, cacique principal de hanansaya, don Martín Coaquila, cacique principal de hurinsaya, don Hernando Yucura, cacique de la isla Amantani -anexa al pueblo-, don Hernando Aparua, segunda persona de hanansaya, don Pedro Caquia, segunda persona de hurinsaya, don Francisco Sanga, segunda persona de Amantani y finalmente Juan Coaquila y Diego Carapongo, caciques de la población uru (Rostworowski, 1985-1986: 64-65). Es probable que Murúa haya interactuado con este elenco cacical durante su oficio como cura de Capachica.

15. Cf. Rostworowski, 1985-1986: 72; AGN IX, 17-1-4. 
16. El poco tiempo de Murúa al frente de la doctrina de Capachica y su escaso conocimiento de la lengua pukina, necesario para la evangelización de la población nativa, son variables que habilitan plantear la continuidad de antiguos cultos prehispánicos e, incluso, preincaicos (Ballesteros Gaibrois, 1987: 10; Bouysse-Cassagne, 2010: 299 y 2014).

17. A más de contar con el aval de otros notables religiosos de la diócesis, en septiembre de 1614 Murúa recibió la validación de don Luis de Quiñones Osorio, gobernador del Tucumán, de quien probablemente tuviera referencias del tiempo que Quiñones ofició como tesorero de la Real Hacienda de Potosí (15961611). Cf. Murúa, 1987: 34-35; Castro Olañeta, 2014.

18. Para las referencias explícitas a los abusos de Murúa, cf. Guaman Poma, ([1615] 2004: 517 [521], 611 [625], 647-648 [661-662], 906 [920], 1080 [1090]. caudal tributario daba cuenta de la riqueza ganadera de sus caciques, quienes además habían conservado su prestigio en términos religiosos -capital simbólico- en tanto garantizaban cierto mantenimiento de cultos prehispánicos de sustrato pukina solapados al calor de la evangelización (Bouysse-Cassagne, 2010). ${ }^{16}$ En efecto, la confluencia entre una alta disponibilidad de riqueza ganadera que derivaba en una especialización textil sostenida y en una clara diferenciación social entre tributarios y caciques -quienes, además, portaban "apellidos" de clara raigambre pukina como don Martín Coaquila- constituían factores que, combinados, hacían de Capachica una prenda por demás asequible tanto para la orden mercedaria, a cargo de la evangelización, como para un religioso recién llegado al Perú y para la familia encomendera beneficiaria de sus tributos. Ello explica, según creemos, la motivación de garantizar la sucesión de la encomienda en favor de don Luis de Peralta y Cabeza de Vaca (Rostworowski, 1985-1986) y el aval que el cura-cronista, fray Martín de Murúa, recibiría en 1612 de parte de don Alonso de Peralta, primer arzobispo de La Plata, para la publicación de su libro (1987: 39; Adorno 2008: 117). Más aún, teniendo en cuenta que don Luis y don Alonso eran hermanos, hijos ambos de don Diego de Peralta, primer encomendero de Capachica (Ramírez del Águila, [1639] 1978: 166 [187v-188r]; cf. Morrone, 2012 y 2013b: 40; Angeli, 2017). ${ }^{17}$

Ya instalado en el convento mercedario del Cuzco, fray Martín de Murúa entabló una intensa relación con otro renombrado miembro de la elite nativa: don Felipe Guaman Poma de Ayala. Durante una primera etapa de trabajo colaborativo en la década de 1590, Guaman Poma diseñó un conjunto de ilustraciones en acuarela que fueron incluidas en la Historia del Origen y Genealogía Real de los Reyes Incas del Perú de Murúa. La relación entre ambos se resintió hacia el cambio de siglo, en parte por la decepción de Guaman Poma al ver sus derechos vulnerados tras perder un pleito por tierras ante la justicia colonial pero, fundamentalmente, al tomar conciencia del licencioso comportamiento del religioso (Ossio, 2008: 78-81). En su propia obra, Guaman Poma acusa específicamente a Murúa de acordar con el corregidor de Aymaraes -donde también había oficiado- la designación de allegados suyos para la cobranza desmedida del tributo indígena, de abusar de mujeres tejedoras e incluso de haber querido seducir y secuestrar a la propia mujer del cronista. Enfatizaba, asimismo, la predilección del religioso por los textiles andinos -lo cual habíamos anticipado en Capachica-, al punto de citar una proclama que el propio Murúa habría proferido contra quienes lo denunciaban frente al encomendero y al corregidor "porque hago tejer ropa y tejidos finos y porque hago hilar a las solteras en mi propia casa” (1615: 611 [625]). Finalmente, Guaman Poma acusaba a Murúa de haber reconstruido la historia incaica a partir de cronistas toledanos sin profundizar sobre la "verdadera" historia incaica "cino todo contra yndios gentiles y de sus rretos y de sus herronías" (1615: 1080 [1090]; Adorno y Boserup, 2005: 223). ${ }^{18}$ Estas acusaciones coinciden con las críticas generalizadas que desde distintos segmentos de la sociedad colonial arreciaron contra los mercedarios por ocuparse más de la acumulación de riquezas y de asuntos seculares que de la efectiva evangelización de la población nativa (Lockhart, [1968] 1982: 74; Álvarez-Calderón Gerbolini, 2004).

A partir de la lectura cruzada de ambas obras de fray Martín de Murúa vimos desfilar importantes figuras de liderazgo regional, las formas en que se articuló la dominación incaica, los atributos del poder y los criterios de legitimidad de los kuraka surandinos, los avatares de la religiosidad nativa en proceso de cristianización y las rispideces operadas entre las figuras de autoridad local -encomenderos, corregidores, curas doctrineros y caciques. Ordenados su spapeles el cronista emprendió un viaje, en busca de avales para su publicación, 
que lo llevaría del Cuzco a La Plata, donde fue nombrado comendador del pueblo de la Limpia Concepción de Nuestra Señora de Huata (corregimiento de Yamparaes, cf. Presta, 2013: 41). De allí partiría a Potosí, al Tucumán y luego al puerto de Buenos Aires para embarcar en 1614 a la península, donde moriría en diciembre de 1615 sin ver su libro salir a la luz. Casi al mismo tiempo otro religioso daba inicio a su obra, rodeado de papeles de archivo, fieles a quienes confesar y prodigios a celebrar.

\section{Milagros y caciques cristianos: Fray Alonso Ramos Gavilán}

Alonso Ramos Gavilán inició la escritura de su obra tras arribar al convento agustino del pueblo de Nuestra Señora de Copacabana en 1618, donde ofició como cura doctrinero. En este sentido, el autor estaba instalado en uno de los centros neurálgicos de la evangelización de las poblaciones indígenas del sur andino. Así como los gobernantes incaicos habían tenido un especial interés en canalizar la sacralidad de ese espacio en función de sus propias estrategias de dominación política e ideológica, tanto el gobierno colonial como la Iglesia procuraron instaurar en Copacabana uno de los ejes vertebradores del proceso evangelizador (Estenssoro Fuchs, 2003: 451-459).

En efecto las primeras décadas del siglo XVII constituyeron una coyuntura clave para la puesta a prueba de la organización del dominio colonial, establecido a partir del último cuarto del siglo anterior. La pronunciada caída demográfica y el inicio de procesos migratorios mostraron las limitaciones del proyecto toledano. En paralelo, en virtud de una bula papal de 1605 y de una real cédula de 1607 la Audiencia de La Plata estableció en 1609 la fragmentación de la jurisdicción del obispado de La Plata, lo cual implicó la erección de dos nuevos obispados -La Paz y Santa Cruz de la Sierra- y el ascenso del obispado charqueño a la dignidad arzobispal. Estos cambios administrativos redundaron en un escenario propicio para el reacomodamiento del clero tanto secular como regular. La instauración de un nuevo solio episcopal en La Paz y el establecimiento del respectivo capítulo catedralicio abrieron camino a las aspiraciones de los religiosos locales, sobre quienes recaería asimismo el control más incisivo de las flamantes y más cercanas autoridades diocesanas. En efecto, a partir de la década de 1610 se abrieron nuevas oportunidades para el despliegue de las carreras eclesiásticas de los curas doctrineros, de modo similar a lo que ocurría para la misma época en los Andes Centrales a partir de las campañas de "extirpación de idolatrías". ${ }^{19}$

En cuanto a la obra de Ramos Gavilán, la misma puede ser entendida como una reivindicación de la labor evangelizadora de la orden agustina en un contexto de competencia entre las distintas órdenes religiosas y entre éstas y el clero secular. La llegada del virrey Toledo a la corte limeña había implicado una ampliación en los márgenes de acción para el clero secular, mientras que para el clero regular significó la asignación de mayores incumbencias a los jesuitas en el campo del adoctrinamiento de las poblaciones nativas. En el marco de su visita general, Toledo ordenó remover a los frailes dominicos de la administración eclesiástica de la gobernación de Chucuito y de la doctrina de Copacabana, asignando esta última al clero secular a cuyo cargo permanecerían hasta enero de 1589, cuando en virtud de tratativas iniciadas por la Audiencia de La Plata -confirmadas por real cédula del 7 de enero de 1588- fue otorgada a los padres agustinos. Su labor catequética y evangelizadora se vio potenciada por el auspicio que la orden ejerció sobre la devoción mariana, que desde inicios de la década de 1580 se desarrollaba en el pueblo. El traslado e instalación de una
19. Sobre las carreras políticoeclesiásticas de los curas doctrineros del Perú colonial, cf. Acosta, 1982a, 1982b, 1987 y 2001; Ganster, [1986] 1992: 163-170; Bravo Guerreira, 1990; Barnadas, 1993; Ramos, 1993; Adrián, 1997 y 2000; Marsilli y Cisternas, 2010; Hidalgo Lehuedé, 2011; Hidalgo Lehuedé et al., 2016. Para Nueva España, cf. el clásico trabajo de Taylor, [1996] 1999 y el más reciente de Lundberg, 2011. 
20. De hecho, Verónica Salles-Reese (1997: 170-171) plantea que la obra de Ramos Gavilán constituye una alternativa a la modalidad "extirpadora", en tanto el religioso proponía un camino hacia la cristianización de la población nativa a través de la internalización y apropiación del cristianismo siguiendo el modelo de cooperación establecido por Agustín de Hipona en De Civitate Dei. Los milagros de la Virgen de Copacabana constituían, en efecto, una instancia de mediación cultural que conectaba el pasado andino con el nuevo escenario colonial cristiano. Cf. asimismo MacCormack, 1984. imagen de la Virgen de la Candelaria, confeccionada por don Francisco Tito Yupanqui en la iglesia central del pueblo, la conformación de una cofradía en torno a la Virgen y la profusión de milagros a ella adjudicados tuvieron una centralidad destacada en la obra de Ramos Gavilán, y es a través de estos canales que vemos en acción a los caciques y otras figuras de autoridad de los pueblos lacustres. Inversamente, y como ya vimos en Murúa, otros caciques aparecen asociados a prácticas tildadas de idolátricas, hechiceriles o, cuanto menos, refractarias y de no-colaboración con el proceso de evangelización. ${ }^{20}$

En términos generales, podemos agrupar a los caciques que aparecen en la obra de Ramos Gavilán en dos grupos, articulados en torno al eje idolatríacristiandad. En el contexto de progresiva evangelización de las élites nativas, el autor narra un conjunto de episodios protagonizados por caciques de diferentes pueblos que o bien persistían en prácticas no cristianas o bien no colaboraban con el adoctrinamiento bajo la fe católica, llegando incluso a la resistencia abierta. Ramos Gavilán remarca cómo en los primeros años del siglo XVII, y a pesar de los esfuerzos de los curas doctrineros, muchos nativos volvían a sus prácticas pre-cristianas liderados por sus respectivos caciques. Siendo cura interino del pueblo de Guacra, cerca de Castrovirreyna, el autor reportó a don Fernando de Mendoza, octavo obispo del Cuzco, el descubrimiento de numerosos objetos de culto o "ídolos". El visitador enviado por el obispo corroboró que los principales adoradores "eran los Curacas o Caziques, que es lo mismo" (I, 14, 1988: 95-97). Asimismo en 1607, Ramos Gavilán presenció en un pueblo de la provincia de Yauyos las exequias fúnebres de un principal: "y noté que quando le llevaban a enterrar, iva toda su parentela cubierta las cabeças, y con hordones en las manos hasta los niños, y niñas". Desconcertado, dio aviso al obispo "para que mandase poner remedio, porque ni pude averiguar el intento de aquella cerimonia, ni persuadirme que no era muy supersticiosa" (I, 22, 1988: 139).

Cerca del Cuzco en 1616 un cacique también reunió a sus parientes para techar una casa nueva, aprovechando la ausencia del cura local el cacique dispuso una gran fiesta que incluyó bailes, repique de campanas e incluso la adoración a un ave: "no me puede suceder cosa mala, pues mi valedor me a visitado", habría dicho a sus parroquianos. Ramos Gavilán fue designado por el obispo para investigar el caso, hallando culpable al cacique "que siguiendo a sus abuelos, y padres, se preciava de hechicero; y temeroso del castigo hizo fuga, dexando su propia patria, dando con sus delitos ocasión al Corregidor, para quitarle el oficio de Cazique" (I, 25, 1988: 160). En mayo de 1617, Ramos Gavilán tuvo la oportunidad de realizar un exorcismo en el pueblo de Ancobamba -corregimiento de Aymaraes. En el proceso, afirmó que para escapar de una imagen de San Juan de Sahagún, el demonio "pidió licencia para entrarse en el cuerpo de un Cazique -principal señor de aquel pueblo-, que allí estava presente, y como nada desto se le consintiesse, congoxávase con demasiado dolor" (I, 15, 1988: 102-103). Si bien la posesión fue conjurada por el exorcista, el hecho de que un cacique pudiera ser "huésped del demonio" resulta acorde a las sospechas que pendían sobre estos líderes étnicos.

Ya asentado en Copacabana a partir de 1618 como cura doctrinero, Ramos Gavilán pudo recolectar testimonios de otros episodios sindicados como hechiceriles, no cristianos o de resistencia protagonizados por los caciques de la región lacustre. A partir de su investigación personal con los archivos del santuario supo cómo un cacique de Pomata (marka lupaqa luego englobada en la gobernación de Chucuito) desobedeció en estado de ebriedad las órdenes de Paullu Inca, quien lo había convocado a Copacabana, probablemente para 
prestar fidelidad en el contexto de la invasión pizarrista al sur andino. El cacique ebrio de Pomata habría respondido: "ya la tierra está por los Españoles, y assí no tiene el Inga que mandarme". Al enviar Paullu por él a unos capitanes para que lo trasladaran a Copacabana, éstos hallaron "que yva en una litera, o guanto (como ellos llaman) en hombros de Indios, a verse con el Inga, por no caer en su desgracia". Los capitanes de Paullu persuadieron al cacique de hablar con él en secreto, y aprovecharon para decapitarlo y presentar luego su cabeza al soberano neo-inca (I, 31, 1988: 188-189). La ebriedad lo llevó a la soberbia, la soberbia al desacato y el desacato a la muerte. ${ }^{21}$

También supo el cronista cómo en 1598 los caciques del pueblo de San Pedro de Sica Sica (corregimiento homónimo) habían ofrendado una niña de diez años "a sus vanos Dioses", encerrándola en una sepultura de grandes dimensiones, siguiendo la práctica incaica de ofrecer mujeres al culto solar (I, 19, 1988: 126). Páginas adelante, Ramos Gavilán presenta una detallada descripción de los enterramientos del Collao, cuyos habitantes "enterraban sus defuntos fuera del pueblo, en los campos, usando unas sepulturas en forma de torresillas, donde juntamente con el defunto, encerravan alguna comida, y bebida, y el vestuario que tenía" (I, 22, 1988: 139). Si tenemos en cuenta que en las cercanías de Sica Sica se han hallado gran cantidad de torres funerarias rectangulares (chullpa) que datan de mediados del siglo XIII (Kesseli y Pärssinen, 2005: 391-393), la actitud de los caciques de ese pueblo hacia finales del siglo XVI estaría dando cuenta de una continuidad en el uso de espacios sacralizados, como así también de una posible legitimación de su liderazgo a través de una identificación con los ancestros petrificados (Morrone, 2015) que Murúa también había denunciado (II, 25, 1987: 416; cf. Cruz, 2014).

En el otro extremo del eje de tensión encontramos a distintas autoridades étnicas consustanciadas con el proceso de evangelización, ya sea en el contexto del traslado e instalación de la imagen de la Virgen en la iglesia de Copacabana, en el establecimiento y difusión del culto mariano a través de la cofradía, como así también protagonizando milagros efectuados por la Virgen. El primero de los aspectos ha recibido mayor atención (Espinoza Soriano, 1972; Castelli, 1990; Salles-Reese, 1997; Bauer y Stanish, 2001; van den Berg, 2002 y 2015; Medinacelli, 2007; Choque Canqui, 2008; del Río, 2009; Costilla, 2010). Sólo repasaremos aquí que tanto el escultor de la imagen de bulto, don Francisco Tito Yupanqui, como sus hermanos don Alonso y don Pablo de Cáceres Viracocha Inga, caciques de la parcialidad hanansaya, obtuvieron la autorización ante las autoridades diocesanas para instaurar el culto a la Virgen de la Candelaria en Copacabana y fundar una cofradía bajo su advocación entre mediados de 1582 y principios de 1583 (II, 4, 1988: 225-228). Como ya señalamos, se trataba de un contexto de redefinición de las relaciones de poder a escala local dado el faccionalismo desatado entre los descendientes coloniales de las panaqa incaicas apostadas en el santuario. Tanto el escultor como los caciques eran hijos de don Baltasar Challco Yupanqui, nietos de Apu Challco Yupanqui y bisnietos de Apu Inga Sucsu, gobernador cuzqueño de Copacabana designado por Topa Inca Yupanqui para custodiar los sitios sagrados del Titicaca y organizar los mitmaqkuna estatales allí establecidos. La facción rival estaba encabezada por don Diego López Churatopa, a la sazón cacique de la parcialidad hurinsaya, hijo de don Gonzalo Churatopa y nieto, asimismo, del gobernador Apu Challco Yupanqui. ${ }^{22} \mathrm{~A}$ esta rivalidad intra-elite se sumaba el desarrollo de un conflicto por tierras entre ambas parcialidades (II, 9, 1988: 245).
21. Recordemos que el privilegio del uso de literas o "andas" estaba limitado a la elite cuzqueña o podía ser concedido a otros líderes locales en reconocimiento a su colaboración con el imperio. Tal como lo señala el propio Ramos Gavilán al relatar el encuentro de Cajamarca en 1532, Atawallpa "yva en hombros de Caziques que eran los grandes de su Reyno" (I, 3, 1988: 34). También reparó en el castigo infligido a los rebeldes: "Quando algún Indio se rebelava mostrándose inobediente a sus mandatos le mandava el Inga colgar de los pies para que assí pendiente con aquel espantoso espectáculo engendrasse escarmiento en el coraçón de otros (y nadie) pena de incurrir en el mismo castigo se atrevía a quitarle de aquel puesto, donde venía a acabar la vida, siendo pasto de los buitres que comúnmente los Indios Naturales Ilaman cóndores" (I, 1, 1988: 26). El lugar de los principales kuraka andinos en el traslado en andas del soberano incaico ya había sido remarcado por fray Martín de Murúa.
22. Comentario de Gonzalo Lamana sobre el artículo de Mercedes del Río (2009: 53). 
23. Don Carlos Acustopa era el hijo mayor de don Baltasar Challco Yupanqui y, por lo tanto, hermano por parte de padre de los caciques del pueblo y del escultor de la imagen (del Río, 2009: 17).
24. Probablemente este cacique haya sido el mismo don Fernando Siñani, encomendado en 1538 en Francisco Carvajal tras ser bautizado, y de quien descendiera la familia cacical que gobernaría el pueblo de Carabuco durante todo el período colonial (Paredes, 1968: 18; Choque Canqui, 1998: 336-337; Quesada, 2006: 492-493). La reconstrucción de Paredes es poco confiable dado que no provee las referencias necesarias para sustentar su narrativa (Spurling, 1992: 53).
La composición inicial de la cofradía fundada en honor a la Virgen echa luz sobre la conformación de alianzas políticas locales en un contexto postoledano. Entre los primeros cofrades encontramos a don Gregorio Marañón corregidor de Omasuyos bajo cuya jurisdicción caía el pueblo de Copacabana, al bachiller don Antonio de Montoro cura del pueblo, al padre Diego de Torres rector del colegio jesuita de Juli, junto a los demás religiosos de la orden que lo acompañaron, y a los caciques de la parcialidad hanansaya don Alonso y don Pablo de Cáceres Viracocha Inga (II, 4-5, 1988: 225-228 y 232-233). Como forma de organización corporativa, la cofradía habilitaba el desarrollo de nuevas solidaridades, alianzas transversales y reconfiguración identitaria para miembros de las elites nativas interesados en mostrarse como "buenos cristianos" (Celestino y Meyers, 1981; Zanolli, 2008; de Luca, 2010). Asimismo verificamos el armado de cadenas de mando y redes relacionales entre caciques y religiosos que trascendían las territorialidades impuestas por el dominio colonial -pueblos de reducción, corregimientos.

Hacia finales de la década de 1580 y frente el rumor de que la imagen de la Virgen sería trasladada a la sede episcopal de La Plata, un grupo de nativos liderado por el cura Montoro ocultaron la imagen en la casa de don Carlos Acustopa, mayordomo de la cofradía. Señala Ramos Gavilán que siendo niño, y mientras servía a los padres dominicos, don Carlos había concurrido

a un conciliábulo, o junta de hechizeros donde en vanos, y supersticiosos ritos adoraban al demonio, el qual sintiendo la presencia del muchacho mandó se le echassen de allí porque era de otra juridición, que no le agradaba el trato de aquellos que la tenían con los Padres (II, 12, 1988: 262-263).

Casi a la inversa de lo ocurrido en el episodio de Ancobamba de 1617, donde el demonio habría visto en el cacique un huésped útil para sus designios, en Copacabana la mera presencia de un miembro de la familia cacical cercano a los dominicos bastó para interrumpir el ritual. ${ }^{23}$

Los caciques también resultaron ser útiles fuentes de información sobre las prácticas religiosas nativas y sobre la historia prehispánica de la región. Ramos Gavilán relata cómo hacia 1600 el cacique don Fernando de Carabuco fue trasladado por el corregidor de Omasuyos hacia el pueblo de Ancoraimes para dar su testimonio sobre las andanzas de un supuesto santo (Tunupa) que, en tiempos antiguos, habría introducido el culto cristiano entre los habitantes del lago. Según el relato del anciano cacique don Fernando, "juzgado por hombre de edad de ciento y veynte años", sus antepasados:

avían visto a un hombre de gran estatura, vestido casi al modo, y trage dellos, blanco, y çarco, que predicava dando vozes, que adorasen un solo Dios, reprehendiendo vicios, y que en compañía de cinco, o seys Indios, que le seguían, traía una Cruz", la famosa Cruz de Carabuco (I, 10, 1988: 70-71) ${ }^{24}$

Dejando atrás los rumores, el apoyo sistemático de la familia cacical y de las autoridades españolas al culto mariano, difundido desde el santuario de Copacabana, se vio retroalimentado por la profusión de milagros realizados por la Virgen, cuya fama trascendió el escenario lacustre y se expandió por el sur andino. Ramos Gavilán presenta un total de 132 milagros, la mayoría de los cuales -más del 80\%- recayeron sobre individuos de diferentes segmentos de la sociedad colonial (Salles-Reese, 1997: 160; Costilla, 2010: 45). Seis de esos milagros individuales fueron protagonizados por caciques y sobre ellos orientaremos nuestra mirada. 
El primer milagro se produjo en 1583, a pocos meses de instalada la imagen de la Virgen en Copacabana. Don Pedro Guanchi, principal del ayllu Chinchaysuyu -parcilaidad hanansaya-, fue milagrosamente sanado de una grave enfermedad que padecía (II, 16, 1988: 281; del Río 2009: 25). Seis años después, la Virgen operó otro milagro sobre Guanchi, su resucitación: "a la vista de todos quitó la Virgen a la muerte su presa, y dio al Indio vida" (II, 17, 1988: 289-290). En 1590 don Gerónimo Achura Callata, cacique principal de Achacachi -corregimiento de Omasuyos-, llevó al santuario a su hijo Francisco Condor, enfermo de "gota coral" (epilepsia) para solicitar su sanación ofreciendo las novenas correspondientes (II, 19, 1988: 298). Otros dos caciques, don Cristóbal Acustopa -hijo de don Carlos Acustopa, mayordomo de la cofradía, ya mencionado- y don Martín Tupa Lupa -cacique principal del pueblo vecino de Yunguyo, gobernación de Chucuito- fueron salvados de la muerte en 1591. Acustopa padecía desde hacía varios años de disentería -infección en el tracto intestinal-, mientras que Tupa Lupa "estuvo a la muerte porque le atormentavan demonios con figuras horribles" - ¿brotes esquizofrénicos? Ambos se presentaron ante la Virgen y obtuvieron su graciosa sanación tras auspiciar sendas misas y, en el caso de Tupa Lupa asentarse como veinticuatro -regidor- de la cofradía (II, 22, 1988: 316).

Finalmente, hacia mediados de 1596 el cacique de Cepita -gobernación de Chucuito- también padecía enfermedades, agravadas mientras preparaba su romería a Copacabana. Al verse imposibilitado de viajar decidió escribir una carta a la Virgen para que lo sanara. En el momento que un pariente suyo partió al santuario, "le cayó al enfermo un sueño repentino, tuvo una iluminación, o habla interior, en que le mandava la Virgen acudiesse a su Santa casa, y que le alcançaría salud". Si bien el cacique inició su viaje, no pudo pasar de Yunguyo. Entre tanto, la carta llegó a Copacabana y los frailes agustinos la pusieron en las manos de la Virgen; al día siguiente el cacique de Cepita pudo llegar y, postrado ante la imagen "sintió el enfermo un gran sudor, de que se halló cubierto, y con aqueste se levantó, y puso en pie y empeçó a andar como si nunca hubiera tenido mal alguno" (II, 28, 1988: 352-353).

Cinco caciques de pueblos lacustres -y uno de ellos en dos oportunidadesfueron protagonistas de los milagros de la Virgen de Copacabana entre 1583 y 1596. Estamos, pues, ante un proceso combinado de doble consolidación, tanto del culto mariano, difundido desde el santuario de Copacabana hacia los distintos espacios que conformaban el mundo andino, como del posicionamiento de los caciques del lago como interlocutores válidos frente a múltiples destinatarios -autoridades del gobierno colonial y de la Iglesia, otros caciques vecinos, autoridades menores y miembros de sus ayllu. La concurrencia al santuario y la devoción mariana operaron en el proceso de construcción de nuevas subjetividades andino-coloniales (Stern, 1987; Costilla, 2010). En tanto "buenos y cristianos" caciques, no sólo fueron actores clave en la difusión de los milagros de la virgen -que, a su vez, atraían más devotos y generaban más milagros- sino que también propiciaron la progresiva conformación e integración de una "comunidad de creencias" entre las elites cacicales de la región.

El eje idolatría/cristiandad es central en la obra de Ramos Gavilán. La participación de los caciques andinos en ambos extremos de la dicotomía le permite al autor dar cuenta del esfuerzo evangelizador de la orden agustina, cuyos vectores más potentes fueron el culto mariano y la profusión de milagros. En efecto, los milagros retroalimentaron la adhesión al culto mariano de la población en general y de los caciques en particular, en una dinámica centrípeta que redundó, según entendemos, en una progresiva integración regional a través 
25. En la información presentada en 1643 ante el Consejo de Indias en solicitud de canonjías o dignidades, aducía haber ejercido el oficio religioso de "mas ha de veinte y çinco años" (AGl, Charcas 92, N. 14, sf. 1r); es decir, aproximadamente desde 1618 , aunque no hallamos registros documentales del sacerdote sino hasta 1630. Sobre Caquiaviri como centro articulador del proceso de evangelización para el siglo XVIII, cf. Querejazu Escobari, 2010.

26. AGN IX, 20-4-4. Ver anexo. Originalmente sin foliación, el documento se encuentra en los folios $218 \mathrm{r}$ $225 \mathrm{v}$ de la numeración efectuada luego de la digitalización del legajo. Sobre la visita del virrey marqués de Mancera, cf. Sánchez Albornoz, 1982 y 1983; Glave, 1995-1996. de mecanismos ideológicos que impactaron en la reconfiguración identitaria de las elites nativas. Durante las décadas centrales del siglo XVII esa identificación sociocultural y los procesos de articulación sociopolíticos protagonizados por los caciques andinos serían puestos a prueba.

\section{El ocaso de los caciques toledanos: el Licenciado Pedro Vallejo de Velasco}

Nuestro tercer caso de estudio difiere de los dos anteriores en más de un aspecto. En primer lugar, el Licenciado Pedro Vallejo de Velasco formaba parte del clero secular, pertenecía a una familia de mediano renombre de la ciudad de La Paz: su padre había sido regidor y su abuelo materno, alguacil mayor del cabildo. Durante la década de 1630, Vallejo de Velasco ejerció el oficio de cura doctrinero en los pueblos de Santa Bárbara de Caquingora -corregimiento de Pacajes- y San Pedro de Moho -corregimiento de Paucarcolla-, coronando su carrera eclesiástica en la década de 1640 como cura de la parcialidad hanansaya del pueblo de la Concepción de la Nueva Toledo de Caquiaviri -cabecera del corregimiento de Pacajes- al tiempo que consolidaba lazos personales y clientelares con la corporación de mercaderes y el cabildo catedralicio de La Paz. Sus vinculaciones con las altas jerarquías diocesanas se tradujeron en su designación como vicario y comisario de la Santa Cruzada del corregimiento, visitador general, predicador general y juez eclesiástico de todo el obispado, cargos que ejerció hasta su muerte, acaecida a principios de 1654 (Morrone, 2013a, y 2017). ${ }^{25}$

A diferencia de Murúa y Ramos Gavilán, Vallejo de Velasco no era un "cronista de convento"; ni siquiera era un cronista. Su inclusión en nuestro estudio obedece al hallazgo de un memorial escrito de su puño y letra en Caquiaviri el 8 de octubre de 1645 . No se trata, en efecto, de una crónica, sino de un texto de ocho folios que acompaña al padrón elaborado por el cura en el contexto de la visita ordenada por el virrey don Pedro de Toledo y Leyva, marqués de Mancera. ${ }^{26}$ En su memorial, como veremos, los caciques tuvieron un protagonismo central.

Hacia la década de 1630 la "disipación" de los pueblos de los corregimientos altiplánicos, originada en la secular caída demográfica, dificultaba la propia reproducción de la actividad minera en Potosí, lo cual provocó enconadas demandas de parte del gremio de azogueros ante las autoridades coloniales -el corregidor de la villa y la Audiencia de La Plata- en pos de actualizar la conformación de los contingentes mitayos que databan de la época toledana y, a la sazón, habían quedado desactualizados (Cole, 1985: 77-87; Bakewell, 1989: 93-103). La disputa por el control y la explotación de la mano de obra nativa -reclamada tanto por los dueños de minas como por los hacendados vallunos- saturó los márgenes de acción de los caciques de cada pueblo y de los capitanes generales de mita, autoridades encargadas del reclutamiento y del entero de los contingentes mitayos (Morrone, 2013b; Zagalsky, 2014).

En 1633 el virrey don Luis Jerónimo de Cabrera y Bobadilla, conde de Chinchón, había autorizado la realización de un nuevo repartimiento de mita que adaptara el abastecimiento del cerro de Potosí a la nueva situación demográfica pero, al promediar la década de 1640, la medida no había dado los resultados esperados. En efecto la visita ordenada por su sucesor, el virrey marqués de Mancera, buscó establecer claramente la composición demográfica de cada pueblo a partir de una distinción a los "naturales" -adultos nacidos en el 
pueblo, sujetos a tributo y mita- de los "forasteros" -migrantes de instalación reciente y exentos de cargas. El recuento de la población y la confección de los respectivos listados o padrones fueron asignados a los curas doctrineros de cada pueblo en función, según entendemos, de su inserción territorial, sus vinculaciones con los caciques y su mejor conocimiento de las realidades locales.

En este contexto, Vallejo de Velasco remarcaba en el informe anexo al padrón que la situación del pueblo de Caquiaviri era particularmente grave: desde 1643, una serie de malas cosechas agudizó la huida de la población. Aunque los caciques principales se afanaban en buscar a los tributarios ausentes muchos fracasaban en sus intentos, al punto de volver a sus pueblos golpeados o lastimados tanto por los propios huidos como por sus empleadores españoles. Tras contabilizar tan solo 664 "indios naturales"; es decir, menos de la mitad de los registrados por la visita toledana Vallejo de Velasco aprovechó la instancia para llevar a cabo un detallado análisis, señalando los principales problemas que atañían al cumplimiento de la mita potosina y recomendando posibles líneas de acción para remediar la crisis de la explotación minera. El texto se organizó en nueve capítulos, seguidos de una serie de advertencias generales que Vallejo de Velasco efectuó para librarse de culpas y cargos que sobre él pudieran levantarse y para que una eventual divergencia de cómputos entre el padrón, los registros parroquiales y las matrículas tributarias "no se atribuya al descuydo ni corta diligençia de mi parte" (sf. 8r).

La despoblación traía aparejado otro efecto disruptivo no menor: la imposibilidad de cumplir con el adoctrinamiento religioso e impartir los sacramentos. Los tributarios huidos "se retiran adonde ni oyen misa ni se confiesan ni viven como cristianos [...] ni todos se confiesan en su pueblo ni se baptizan los hijos en el porque los mas andan juntamente con sus mugeres" (sf. 1v y 2v). Aun cuando los caciques no siempre podían resolver el reclutamiento de los tributarios huidos, también se daba el caso de que los propios caciques defeccionaban: "Estos tales caciques siendo como son borrachos en general e yncapaces los mas, comen y beben lo que pueden, y quando se hallan empeñados, y acoçados de trabajo y obligaciones son los primeros que se ban" (sf. $2 \mathrm{v}$ ). En la prosa de Vallejo de Velasco, como vemos, los caciques adquieren un rol protagónico.

La clásica asociación entre ocio y vagancia, borracheras e "idolatría" justificaba, según el cura, la imposibilidad de los caciques de cumplir su función de intermediación en el entero de la mita. Sin embargo, desde una perspectiva andina, el consumo de comida y bebidas alcohólicas en abundancia puede ser leído como una práctica que buscaba convalidar sus posiciones de autoridad hacia el interior de sus ayllu. La potencia física constituía uno de los criterios claves del liderazgo político en términos nativos, más aún en un contexto en el que su posición de intermediación se encontraba amenazada por el recrudecimiento de las obligaciones coloniales (Saignes, 1987a).

Vallejo de Velasco advertía asimismo que las sospechas que tradicionalmente habían recaído sobre los caciques -ocultamiento de tributarios, desvío de bienes tributados- ya no eran acertadas en un contexto de aguda caída demográfica. Su balance sobre el rol de caciques como garantes de la reproducción de las relaciones de dominación colonial era taxativo: "oy no pueden distribuyr tanta carga en tan pocos [...] si bien algunos caciques que tienen govierno conserban sus pueblos pero son muy raros, y finalmente conforme es el cacique asi esta cada pueblo" (sf. 2v-3r). Si bien las autoridades superiores solicitaban 
[...] se busquen los mas capaces para hazerles caciques, estos no los ay en todos los pueblos, ni en ningun linage de hombres se conoce el capaz sino con la experiencia porque los mas no son lo que parecen y esto que pudieran tantear en alguna manera los corregidores al primer que lo son abren los ojos del conocimiento, al segundo los quitan con que siempre es el govierno a çiegas (sf. 3r).

La intervención de las autoridades coloniales en la designación de caciques por fuera de los linajes que databan -al menos- de la época toledana tampoco era la solución, toda vez que los caciques designados no manifestaban las habilidades necesarias y, si lo hacían, rápidamente se desentendían de sus obligaciones o encontraban resistencia por parte de los tributarios -situación para la cual no contamos con documentación de esta época.

Este proceso de crisis en las prácticas de articulación socioeconómica que Vallejo de Velasco diagnosticaba al promediar el siglo XVII podría conceptualizarse como una segunda coyuntura de "declinación de los señores tradicionales" (Saignes, 1987b), proceso que presentaba, asimismo, correlatos materiales en aspectos más sutiles como lo eran la indumentaria y los hábitos del vestir (Presta, 2010). Si en años más auspiciosos "avia algunos caciques capaces y de caudal y que se vestian y trataban con luzimiento y por aver ydo por capitanes de mita", para 1645 Vallejo de Velasco se indigna al evidenciar que sus caciques y capitanes de mita contemporáneos se encontraban "tan desdichados que andan con capas remendadas de diferentes colores (que ya no alcançan mas)" (sf. 4v-5r). En una sociedad estamental, la vestimenta era un atributo clave entre las elites nativas en pleno proceso de occidentalización y mestizaje cultural (Ares Queija y Gruzinski, 1997). En términos andino-coloniales, la pobreza del vestir implicaba una mácula estatutaria, la progresiva destrucción del capital simbólico hasta entonces acumulado y el ingreso en una espiral descendente que llevaba a la imposibilidad de reproducir la mediación cultural. Podríamos imaginar el pasmo que hubiera causado en fray Martín de Murúa la vivencia del descuido, pobreza y desaliño de los caciques de Caquiaviri en su vestimenta, habiendo sido él tan afecto a los textiles de fino cumbi que había adquirido durante su oficio en Capachica seis décadas atrás.

Incluso en términos "más materiales" -si cabe tal distinción-, el acceso al cargo de capitán de mita había pasado de ser un terreno de disputas a conformar una obligación a eludir. Vallejo de Velasco remarca que

por lo menos cuesta a cada capitan de quinze a veinte mil pesos la capitania, y oy aviendo menos destos se ha tomado medio en Potosi hazer dos capitanes generales (que cada pueblo ya se save da el suio particular) para que asistiendo el uno ande el otro recogiendo gente (sf. 5r).

El proceso de desgranamiento de las capitanías de mita databa de la década de 1610 (Saignes y Loza, 1984) y, según el diagnóstico de Vallejo de Velasco, para 1645 el rol de estas autoridades se hallaba profundamente tergiversado, al punto de que no pudiendo reducir la cantidad de mitayos estipulada "es çierto que ni aun cantores ni sacristanes dejan en las yglesias" (sf. 5r). En cualquier caso, los caciques y capitanes de mita debían hacerse cargo de reponer de sus propios bienes el faltante de mitayos -muertos o huidos.

Otra desviación del orden toledano denunciada por Vallejo de Velasco radicaba en el trastorno de los criterios establecidos para la consideración de un "cacique estimado". En efecto, si 
En los pasados estimaban grandemente en comun el ser caciques los yndios, porque el mandar es apetito e ynclinaçion natural, oy los de los valles y lugares de donde no se mita a Potosí lo pretenden grandemente, y sobre serlo tienen grandes pleytos alegaçiones sobre pertenecerles por erençia de sus pasados (sf. 5v).

El hecho de que los caciques altiplánicos buscaran diferentes formas de eludir sus obligaciones, sea haciendo dejación de los cargos o huyendo de sus pueblos, evidencia que esa posición de autoridad había dejado de ser un objetivo apetecible y había devenido, más bien, en una amenaza (Morrone, 2015 y 2016). Hacia mediados del siglo XVII el rol de articulador sociopolítico y aglutinante identitario ejercido por las autoridades nativas, una de sus funciones claves en el esquema toledano, se hallaba absolutamente desnaturalizado. La caída en desgracia de los caciques altiplánicos implicó, asimismo, un "efecto amnésico": si los caciques constituían un vértice de convergencia de la memoria colectiva -de sus ayllu- y de la memoria genealógica -de sus linajes-, al debilitarse su rol mediador y sus capacidades de articulación también se veía amenazada la reproducción de los canales por los cuales se (re)construían las secuencias de la memoria: contadas eran las autoridades que "han quedado (los que parecen que los demás ya se los ha tragado la tierra segun falta la memoria dellos)" (sf. 4v-5r; Abercrombie, [1998] 2006). De modo análogo, cabe formular este interrogante en torno a las capacidades mnemónicas de los khipucamayoq devenidos en "contadores", de quienes tanto hablaba Murúa, ¿se habrán fortalecido estas autoridades menores frente al colapso de los caciques principales, o habrán caído en desgracia junto a ellos?

En términos generales, el balance de Vallejo de Velasco es rotundo: al promediar el siglo XVII, los ejes nodales del orden toledano -reducción a pueblos de indios, asignación de la séptima parte de la masa tributaria para la mita potosina, rol articulador de los caciques y capitanes de mita, evangelización a cargo de los curas doctrineros- eran meras evocaciones de un tiempo que ya no volvería, tristes nostalgias de una época añorada. Si bien el cura arriesgaba algunas líneas de recomposición -reemplazo de mitayos ausentes por yanaconas reales, reducción de la séptima toledana-, la situación había llegado a un punto crítico y ya no había un pronóstico favorable, "porque entender que se pueda de otra manera alentar esta tierra tan cayda y ya tan declarada para sus fines miserables es ynposible y es de manera que si no se abrebia con el remedio quedara sin remedio alguno" (sf. $7 \mathrm{v}$ ).

\section{Consideraciones finales}

Nos propusimos indagar acerca de las caracterizaciones de los caciques coloniales de la cuenca del lago Titicaca, a partir del relato de tres curas doctrineros que ejercieron sus oficios en esa región. La premisa original sostenía que el anclaje territorial de estos curas, y su conocimiento del quehacer diario de sus respectivas feligresías, constituían ventanas de acceso para el análisis de las figuras de liderazgo étnico y de los vínculos entablados entre ellos. A poco de andadas las lecturas, verificamos que los panoramas ofrecidos por los tres curas-cronistas excedían tanto el rango temporal -a partir de referencias al pasado incaico- como el marco espacial -tras sus derroteros por varias jurisdicciones diocesanas- inicialmente delimitados.

Entre altares y escritorios, la pluma de estos tres curas-cronistas nos permitió dar cuenta de sus respectivos "balances de situación" sobre el proceso de 
evangelización y el rol de los propios curas doctrineros, la "permeabilidad" de la población nativa, la capacidad mediadora de las autoridades étnicas y su participación en el armado del poder local. Llegados a este punto, nos interesa trazar posibles líneas de confluencia, divergencia y/o diálogo a través del análisis integrado de los tres casos.

Cada contexto sociohistórico condicionó tanto las realidades retratadas por los curas-cronistas como sus propias percepciones. Los tres autores elaboraron sus obras en centros neurálgicos del poder colonial: el Cuzco -antigua capital del imperio incaico-, Copacabana -santuario prehispánico devenido en sede del culto mariano más importante de la región- y Caquiaviri -cabecera de uno de los corregimientos más ricos en mano de obra y ganado del altiplano collavino. Sus respectivas carreras político-eclesiásticas los habían conducido por distintos rincones del mundo andino, donde no sólo acumularon experiencia en el oficio religioso sino que también perfilaron sus propias perspectivas, diagnósticos y modos de ver la realidad colonial. Cada uno en su tiempo, y en virtud de la confluencia de múltiples factores, fueron referentes de sus propios círculos sociales, religiosos y culturales. En algún momento, los caminos recorridos y las experiencias adquiridas los habilitaron para alzar la pluma, aquella que utilizaban para completar los registros parroquiales o elaborar sus sermones, para redactar obras con el objetivo de dejar a la posteridad sus reflexiones y pareceres al respecto de la sociedad que tenían "a vista de ojos".

Tal como muchos otros curas doctrineros del Perú colonial, nuestros tres cronistas desplegaron sus carreras a través de varias doctrinas en busca de mejores posiciones dentro del campo eclesiástico. Murúa ofició como cura doctrinero de Capachica para luego ingresar en el convento mercedario del Cuzco, desde donde se proyectó hacia Arequipa, el corregimiento de Aymaraes y, culminada su obra, la diócesis de La Plata. Por su parte, Ramos Gavilán antes de llegar a Copacabana había ocupado varias doctrinas en los corregimientos de Yauyos y Aymaraes, mientras que Vallejo de Velasco circuló entre, al menos, tres doctrinas del altiplano lacustre -Caquingora, Moho y Caquiaviri. En cuanto a sus respectivas pretensiones, sólo Ramos Gavilán pudo ver su obra publicada en 1621 antes de morir; Murúa moriría al poco tiempo de regresar a España, mientras que Vallejo de Velasco no pudo acceder a las dignidades que solicitó ante el Consejo de Indias en 1638 y en 1643.

Por otro lado, el rol que cupo a los caciques andinos en las obras aquí trabajadas fue dispar. En Murúa observamos a los caciques y a otras figuras andinas de autoridad ocupando distintas posiciones en los esquemas de dominación incaico y colonial; en Ramos Gavilán la tensión central está dada por su protagonismo entre la pervivencia de cultos prehispánicos tildados de idolátricos y la consolidación del proceso de evangelización a través del culto mariano, mientras en Vallejo de Velasco los caciques son tanto víctimas como victimarios de la descomposición del orden toledano construido en torno a los pueblos de reducción y la mita potosina. En definitiva, los tres curas ofrecen perspectivas complementarias tanto sobre el devenir de la dominación colonial como de los márgenes de acción disponibles para los caciques en cada coyuntura.

Aspectos como el consumo desmedido de comida, las bebidas alcohólicas y otras sustancias psicotrópicas y la evidencia de cierta continuidad de prácticas prehispánicas de religiosidad, incluidas de distintas formas en los relatos de los tres curas-cronistas, permiten escudriñar, cuanto menos de manera indicial, algunos atributos que contribuyeron a reproducir la legitimidad interna de los caciques coloniales; es decir, aquella que, expresada en términos 
"andinos", emanaba de los ayllu y sostenía la posición intermediaria de las autoridades étnicas. Si bien desde lo discursivo los curas doctrineros debían repudiar, denunciar y conjurar esas conductas, desde la lógica cotidiana de la reproducción de la dominación colonial toleraron -cuando no propiciaron-, ciertos márgenes de acción en tanto los caciques proveyeran cuotas mínimas de observancia de la doctrina católica. De ahí el principal interés de muchos caciques por mostrarse como "buenos cristianos", más allá -o más acá- de sus efectivas creencias y prácticas religiosas.

Claro está que las relaciones entabladas entre curas doctrineros y caciques distaron de responder a un único patrón. Más allá de los indicios ofrecidos en los manuscritos de los tres religiosos reseñados y en la documentación complementaria, la hipótesis de trabajo que sugerimos en este punto atiende a los "pesos políticos específicos" que cada actor pudo construir a lo largo de sus respectivas carreras y en virtud de las diferenciales dotaciones de capital -económico, social, político, simbólico- disponible. Esta disputa habrá redundado, en cada escenario local, en distintas configuraciones políticas tensadas por vectores asociados a cada figura de liderazgo. Así, a finales de la década de 1570 el accionar de Murúa pudo haberse visto condicionado tanto por su situación de recién llegado al altiplano como por la influencia política de los prestigiosos caciques de Capachica, sustentada en su riqueza ganadera y textil heredada en buena medida de épocas prehispánicas. En el otro extremo, la situación de los "devaluados" caciques y capitanes de mita del corregimiento de Pacajes de la década de 1640 contrastaba de lleno con la meteórica carrera eclesiástica y las redes sociales fraguadas por Vallejo de Velasco, que brindaban al religioso campos de acción más amplios para el despliegue de sus negocios y alianzas políticas. Un ejercicio complementario consistiría en evaluar diacrónicamente cada escenario local, a partir de incorporar documentación para cada caso ¿Cómo habrán interactuado, por ejemplo, los curas doctrineros de Caquiaviri en el período 1570-1600, coyuntura en la que los caciques de ese pueblo estaban mucho mejor posicionados en el armado de las redes del poder local?; ¿pudieron los caciques de Capachica sostener su posición de prestigio más allá del cambio de siglo, siendo que para 1645 la población tributaria había caído en un $93 \%$ con respecto a la época toledana?; ¿es posible establecer correlaciones entre variables cuantitativas -población, bautismos y defunciones, flujos migratorios- y variables cualitativas -potencia política de las figuras de liderazgo, tanto étnico como religioso-?; ¿cómo ponderar la multiplicidad de variables que entraron en juego a la hora de analizar la dinámica política local?

Estos interrogantes cobran particular interés a la luz de la escasa evidencia, en los Andes meridionales, de los procesos de "extirpación de idolatrías" que caracterizaron el campo socio-religioso de los Andes centrales para la primera mitad del siglo XVII, la cual podría explicarse por el establecimiento de pactos de complicidad -tácitos o explícitos- entre curas y caciques en tanto articuladores del poder local (Saignes, 1984: 45; cf. Barnadas, 1993; Morrone, 2010b y 2017).

Vistos en conjunto los tres curas-cronistas ofrecen sucesivas panorámicas del período 1570-1650, décadas centrales en la puesta en juego de las relaciones de dominación colonial en su "configuración toledana". La inserción de los curas doctrineros en las realidades locales del mundo andino permite no sólo seguir sus carreras eclesiásticas sino también las vinculaciones con los caciques y con los corregidores de indios, vinculaciones cotidianas que conformaban verdaderas redes situadas de poder. Las plumas de Murúa, Ramos Gavilán y 
Vallejo de Velasco dejaron trazos en tinta de sus realidades contemporáneas en forma de producciones escritas que, desde el presente, fatigamos para evocar, reconstruir y deshilvanar las relaciones de dominación colonial.

\section{Agradecimientos}

Una versión anterior de este trabajo fue presentada en las XVI Jornadas Interescuelas/ Departamentos de Historia, organizadas por la Universidad Nacional de Mar del Plata del 9 al 11 de agosto de 2017. Agradecemos los aportes realizado por Isabel Castro Olañeta, Germán Morong Reyes y María Fernanda Percovich en aquella ocasión, como así también las sugerencias de María Laura Cutrera y la atenta lectura de Lía Guillermina Oliveto. Este trabajo fue realizado en el marco de los Proyectos PICT 2016-0481 y UBACyT F291, ambos bajo la dirección de Ana María Presta.

\section{Notas}

3. Memorial a Felipe II (1588), y a Pedro Ramírez del Águila, cura de San Pedro de Tacobamba (corregimiento de Porco), autor de Noticias Políticas de Indias (1639). Sobre el primero, cf. Albó, 1999 y Galdames Rosas y Álvarez Miranda, 2001-2002; sobre el segundo, cf. Zagalsky, 2014 y Sierra Martín, 2016. (En página 54). 


\section{Fuentes documentales}

" Archivo General de Indias (AGl). Charcas 92, N. 14. Papeles y títulos del Licenciado Pedro Vallejo de Velasco (1643).

» Archivo General de la Nación (AGN). Sala IX, Legajo 17-1-4. Padrones de indios. Alto Perú 1645-1686.

» Archivo General de la Nación (AGN). Sala IX, Legajo 20-4-4. Padrones de indios. Alto Perú 1623-1646.

» Archivo General de la Nación (AGN). Sala XIII, Legajo 17-2-3. Padrones de indios. Omasuyos 1579-1684. 


\section{Q Bibliografía}

» Abal de Russo, C. M. (2010). Arte Textil Incaico en Ofrendatorios de la Alta Cordillera Andina: Aconcagua, Llullaillaco, Chuscha. Buenos Aires, Fundación CEPPA.

»Abercrombie, T. ([1998] 2006). Caminos de la Memoria y del Poder. Etnografía e historia de una comunidad andina. La Paz-Lima, IEB-IFEA.

» Acosta Rodríguez, A. (1982a). Los doctrineros y la extirpación de la religión indígena en el arzobispado de Lima, 1600-1620. Jahrbuch für Geschichte Lateinamerikas 19: 69-109.

» Acosta Rodríguez, A. (1982b). Religiosos, doctrinas y excedente económico indígena en el Perú a comienzos del siglo XVII. Histórica VI (I): 1-34.

» Acosta Rodríguez, A. (1987). La extirpación de las idolatrías en el Perú. Origen y desarrollo de las campañas. A propósito de Cultura andina y represión, de Pierre Duviols. Revista Andina 9: 171-195.

» Acosta Rodríguez, A. (2001). Dogma católico para indios: la versión de la Iglesia del Perú en el siglo XVII. Histórica XXV (2): 11-47.

» Adorno, R. (2004). Estudiosos y censores de la Historia General del Perú (1611-1613) de fray Martín de Murúa. Letras LXXV (107-108): 47-72.

" Adorno, R. (2008). “Censorship and approbation in Murúa's Historia General del Piru” en Cummins T. y B. Anderson (eds.), The Getty Murúa. Essays on the making of Martín de Murúa's ‘Historia General del Piru’. Paul Getty Museum Ms. Ludwig XIII 16: 95-124. Los Angeles, The Getty Research Institute.

» Adorno, R. e I. Bosserup (2005). Guaman Poma and the manuscripts of Fray Martín de Murúa. Prolegomena to a critical edition of the Historia del Perú. Fund og Forskning 44: 107-246.

»Adorno, R. e I. Boserup (2008). “The making of Murúa’s Historia General del Perú” en Cummins T. y B. Anderson (eds.), The Getty Murúa. Essays on the making of Martín de Murúa’s ‘Historia General del Piru’. Paul Getty Museum Ms. Ludwig XIII 16: 7-75. Los Angeles, The Getty Research Institute.

» Adrián, M. (1997). El espacio sagrado y el ejercicio del poder. Las doctrinas de Chayanta durante la segunda mitad del siglo XVII. Anuario del Archivo y Biblioteca Nacionales de Bolivia 3: 239-255.

»Adrián, M. (2000). Estrategias políticas de los curas de Charcas en un contexto de reformas conflictividad creciente. Andes 11: 135-160.

»Aguinagalde Olaizola, F. B. de. (2017). Un misterio resuelto. El autor de la Historia General del Perú, Fray Martín de Murúa (1566?-1615), de Eskoiratza. Donostia-San Sebastián, Philobiblion. Sociedad de Bibliófilos de Guipuzcoa.

» Albó, X. (1999). Un clérigo muy particular ante los indios de Charcas (Bolivia) y su memorial de 1588 recién publicado. Revista de Dialectología y Tradiciones Populares LIV (1): 189-206.

» Álvarez-Calderón Gerbolini, A. (2004). Fray Martín de Murúa y su crónica: vida, obra y mentiras de un mercedario en los Andes (fines del siglo XVI-principios del XVII). Boletín del Instituto Riva-Agüero 31: 97-154.

»Angeli, S. H. (2017). “ni era necesario auer escrito tan largo en derecho”. Argumentación 
jurídica del oidor Sebastián Zambrana de Villalobos para casar a su hijo en la jurisdicción de la Audiencia de Charcas, siglo XVII. Prohistoria 27: 23-35.

»Ares Queija, B. y S. Gruzinski (coords.) (1997). Entre Dos Mundos. Fronteras culturales y agentes mediadores. Sevilla, CSIC-EEHA.

» Arkush, E. N. (2009). Pukaras de los Collas: guerra y poder regional en la cuenca norte del Titicaca durante el Periodo Intermedio Tardío. Andes 7: 463-479.

》 Arkush, E. N. (2011). Hillforts of the Ancient Andes: Colla Warfare, Society, and Landscape. Gainsville, University Press of Florida.

" Bakewell, P. (1989). Mineros de la Montaña Roja. El trabajo de los indios en Potosí. 1545-1650. Madrid, Alianza.

》 Ballesteros Gaibrois, M. (1987). “Introducción” en Murúa, M., Historia General del Perú: 5-29. Madrid, Historia 16.

" Barnadas, J. M. (1993). “Idolatrías en Charcas (1560-1620): datos sobre su existencia como paso previo para la valoración del tema de su extirpación" en Urbano H. y G. Ramos (comps.), Catolicismo y extirpación de idolatrías. Siglos XVI-XVIII: 89-104. Cuzco, Centro Bartolomé de Las Casas.

"Bauer, B. S. y C. Stanish (2001). Ritual and Pilgrimage in the Ancient Andes. The islands of the Sun and the Moon. Austin, University of Texas Press.

" Bouysse-Cassagne, T. (1978). L'espace aymara: urco et uma. Annales ESC 33 (5-6): 10571080.

》 Bouysse-Cassagne, T. (1988). Lluvias y Cenizas. Dos Pachacuti en la Historia. La Paz, Hisbol.

" Bouysse-Cassagne, T. (2010). Apuntes para la historia de los puquina hablantes. Boletín de Arqueología PUCP 14: 283-307.

» Bouysse-Cassagne, T. (2014). "Endoctriner, normaliser, discriminer: l'utopie jésuite de Juli (XVe-XVIle siècle)" en Garavaglia, J. C. Poloni-Simard J. y G. Rivière (dirs.), Au Miroir de l'Anthropologie Historique. Mélanges offerts à Nathan Wachtel: 401-414. Rennes, PUR.

» Bravo Guerreira, M. C. (1990). "El clero secular en las doctrinas de indios del Perú. Siglo XVI" en Saranyana, J-I; Tineo, P.; Pazos, A. M.; Lluch-Baixaulli, M. y M. P. Ferrer (eds.), Evangelización y teología en América (siglo XVI) 1: 627-642. Pamplona, Servicio de Publicaciones de la Universidad de Navarra.

" Castelli, A. (1990). Copacabana: un ejemplo de simbolismo religioso en el altiplano. Histórica XIV (2): 355-365.

»Castro Olañeta, I. (2014). “Las cartas del gobernador del Tucumán don Luis de Quiñones Osorio al rey de España. Un estudio preliminar” en Piana J. e l. Castro Olañeta (eds.), Visita y Padrón de los Indios del Distrito de Córdoba, Provincia del Tucumán. 1616-1617: 243260. Córdoba, EDDUC.

" Celestino, O y A. Meyers (1981). Las Cofradías en el Perú. Región Central. Frankfurt, Iberoamericana.

" Cereceda, V. (2014). "Transformaciones en diseños textiles originarios. ¿Transformaciones en la vida social?" Conferencia magistral dictada en el IX Congreso Internacional de Etnohistoria. Departamento de Ciencias Históricas y Geográficas, Facultad de Educación y Humanidades, Universidad de Tarapacá. Arica, 10 al 14 de noviembre.

"Choque Canqui, R. (1998). "El parentesco entre los caciques de Pakasa" en Arnold D. Y. (comp.), Gente de Carne y Hueso. Las tramas del parentesco en los Andes II: 325-340. La Paz, CIASE-ILCA. 
"Choque Canqui, R. (2008). Los inkas de Copacabana y la invasión europea. Anuario de Estudios Bolivianos, Archivísticos y Bibliográficos 14: 155-172.

»Cole, J. A. (1985). The Potosí Mita 1573-1700. Compulsory Indian labor in the Andes.Stanford, Stanford University Press.

»Cook, N. D. (1975). Tasa de la Visita General de Francisco de Toledo. Lima, UNMSM.

»Costilla, J. (2010). El milagro en la construcción del culto a Nuestra Señora de Copacabana (virreinato del Perú, 1582-1651). Estudios Atacameños 39:35- 56.

" Covarrubias, S. de ([1611] 1943). Tesoro de la Lengua Castellana o Española. Barcelona, Horta.

"Cruz, P. (2014). Desde el diabólico mundo de los gentiles. Lecturas sobre un pasado muy presente en el espacio alto-andino de Potosí y Chuquisaca (Bolivia). Revista Española de Antropología Americana 44 (1): 217-234.

"Cummins, T. y J. Ossio (2014). “'Muchas veces dudé Real Mag. açeptar esta dicha ympressa'. La tarea de hacer La Famossa Historia de los Reyes Incas de Fray Martín de Murúa" en Garavaglia, J. C.; Poloni-Simard J. y G. Rivière (dirs.), Au Miroir de l'Anthropologie Historique. Mélanges offerts à Nathan Wachtel: 151-170. Rennes, PUR.

» de la Puente Luna, J. C. y M. Curatola Petrocchi (2013). El Quipu Colonial. Estudios y materiales. Lima, PCUP.

» de la Vega, E. y C. Stanish (2002). Los centros de peregrinaje como mecanismos de integración política en sociedades complejas del altiplano del Titicaca. Boletín de Arqueología PCUP 6: 265-275.

" de Luca, M. C. (2010). Las cofradías de indios en el territorio de Charcas (siglo XVIII): balance historiográfico y nuevas propuestas de análisis. Cambios y Permanencias 1: 94-117.

» del Río, M. (2009). De sacerdotes del Tawantinsuyu a cofrades coloniales: nuevas evidencias sobre los Acustopa y Viracocha Inga de Copacabana. Revista Andina 46: 6-69.

»Escandón, P. (2015). La Historia General del Perú de fray Martín de Murúa como relación de méritos y servicios. Mnemosine Revista 6 (1): 95-180. Disponible en Internet: http:// www.bibliotekevirtual.org/revistas/UFCG/MNEMOSINE/vo6no1/vo6no1ao6.pdf. Consultado el: 5 de mayo de 2017 .

»Espinoza Soriano, W. (1972). Copacabana del Collao. Un documento de 1548 para la etnohistoria andina. Bulletin de l'IFEA 1 (1): 1-16.

"Espinoza Soriano, W. (1987). Migraciones internas en el reino Colla. Tejedores, plumeros y alfareros del estado imperial Inka. Chungara 19: 243-289.

»Estenssoro Fuchs, J. C. (2003). Del Paganismo a la Santidad. La incorporación de los indios del Perú al catolicismo. 1532-1750. Lima, PUCP-IFEA.

"Frye, K, L. y E. de la Vega (2005). "The Altiplano Period in the Titicaca basin" en Stanish, Ch.; Cohen A. B. y M. S. Aldenderfer (eds.), Advances in the Archaeology of the Titicaca Basin: 173-184. Los Angeles, University of California Press.

» Galdames Rosas, L. A. y L. Álvarez Miranda (2001-2002). El soporte cultural que sustenta el discurso de Bartolomé Álvarez. Diálogo Andino 20-21: 73-80.

" Ganster, P. ([1986] 1992). “Religiosos” en Hoberman, L. S. y S. M. Socolow (comps.), Ciudades y Sociedad en Latinoamérica Colonial: 141-174. México: FCE.

» Glave, L. M. (1995-1996). Familia y poblamiento en el altiplano andino. Siglo XVII. Andes 7: 89-112.

» Guaman Poma de Ayala, F. ([1615] 1992). Nueva Corónica y Bueno Gobierno, John V. 
Murra, J. V.; Adorno R. y J. L. Urioste (transcriptores). Disponible en Internet: http:// www.kb.dk/permalink/2006/poma/info/es/frontpage.htm Consultado el: 4 de abril 2017.

» Hidalgo Lehuedé, J. (2011). Redes eclesiásticas, procesos de extirpación de idolatrías y cultos andinos coloniales en Atacama. Siglos XVII y XVIII. Estudios Atacameños 42: 113152.

» Hidalgo Lehuedé, J.; Marsilli C, M. y J. Aguilar (2016). Redes familiares, carreras eclesiásticas y extirpación de idolatría. Doctrina de Camiña, Tarapacá. Siglo XVII. Chungara 48 (3): $409-428$.

» Julien, C. ([1983] 2004). Hatunqolla. Una perspectiva sobre el imperio incaico desde la región del lago Titicaca. La Paz, CIMA.

» Kesseli, R. y M. Pärssinen (2005). Identidad étnica y muerte: torres funerarias (chullpas) como símbolos de poder étnico en el altiplano boliviano de Pakasa (1250-160o d. C.). Bulletin de l'IFEA 34 (3): 379-410.

» Lockhart, J. ([1968] 1982). El Mundo Hispanoperuano. 1532-156o. México, FCE.

» Lundberg, M. (2011). Church Life Between the Metropolitan and the Local. Parishes, Parishioners and Parish Priests in Seventeenth-Century Mexico. Madrid, Iberoamericana-Vervuert.

» MacCormack, S. (1984). From the sun to the Incas to the Virgin of Copacabana. Representations 8: 30-59.

» Marsilli, M. N. y P. Cisternas (2010). Los senderos de la idolatría: el viaje de Vázquez de Espinosa por los Altos de Arica, 1618. Chungara 42 (2): 465-476.

» Matute, A. (1997). Crónica: historia o literatura. Historia Mexicana 184, 46 (4): 711-722.

» Maurtúa, V. M. (1906). Juicio de Límites entre Perú y Bolivia. Madrid, Imp. Hernández.

» Medinacelli, X. (2007). Paullu y Manco ¿una diarquía inca en tiempos de conquista? Bulletin de l'IFEA 36 (2): 241-258.

» Morong Reyes, G. (2016). Saberes Hegemónicos y Dominio Colonial. Los indios en el Gobierno del Perú de Juan de Matienzo (1567). Rosario, Prohistoria.

» Morrone, A. J. (2010a). Clero rural y liderazgo étnico en el corregimiento de Pacajes: la antigua iglesia de Jesús de Machaca (siglo XVII). Anuario de Estudios Bolivianos, Archivísticos y Bibliográficos 16: 445-475.

» Morrone, A. J (2010b). Legitimidad, genealogía y memoria en los Andes meridionales: los Fernández Guarachi de Jesús de Machaca (Pacajes, siglos XVI-XVII). Memoria Americana. Cuadernos de Etnohistoria 18 (2): .211-237

" Morrone, A. J (2012). De "señores de indios" a nobles rentistas: los encomenderos de La Paz (1548-1621). Surandino Monográfico. Segunda sección de Prohal Monográfico II (2). Disponible en Internet: http://www.filo.uba.ar/contenidos/investigacion/institutos/ravignani/prohal/mono.html. Consultado el: 16 de diciembre de 2016.

» Morrone, A. J. (2013a). Curas doctrineros y caciques andinos en la construcción de legitimidades: las iglesias rurales de La Paz (Audiencia de Charcas, 1570-1630). Jahrbuch für Geschichte Lateinamerikas 50: 29-54.

" Morrone, A. J. (2013b). "Estrategias estatales y liderazgo étnico en el corregimiento de Pacajes (1538-1620)" en Presta, A. M. (ed.), Aportes Multidisciplinarios al Estudio de los Colectivos Étnicos Surandinos. Reflexiones sobre Qaraqara-Charka tres años después: 343-372. Lima-La Paz, IFEA-Plural.

» Morrone, A. J. (2015). Tras los pasos del mitayo: la sacralización del espacio en los corregimientos de Pacajes y Omasuyos (1570-1650). Bulletin de l'IFEA 44 (1): 91-116. 
» Morrone, A. J. (2016). No todos los caciques fueron mallku. Mediación política truncada en los corregimientos de Pacajes y Omasuyos (1570-1650). Diálogo Andino 50: 207-217.

» Morrone, A. J. (2017). El lago de los curas. Mediación sociopolítica y cultural en los corregimientos del lago Titicaca (1570-1650). Estudios Atacameños 55: 183-202.

» Murra, J. V. (1975). Formaciones Económicas y Políticas del Mundo Andino. Lima, IEP.

» Murra, J. V. ([1955] 1999). La Organización Económica del Imperio Inca. México, Siglo XXI.

» Murúa, M. de ([1590] 1946). Historia del Origen y Genealogía Real de los Reyes Incas del Perú. Madrid, Ed. Constantino Bayle, SJ. - CCSIC.

» Murúa, M. de ([1611-1613] 1987) Historia General del Perú. Madrid, Ed. Manuel Ballesteros Gaibrois, Historia 16.

» Ossio, J. M. (1998). Research note. El original del manuscrito Loyola de Fray Martín de Murúa. Colonial Latin American Review 7 (2): 271-278.

» Ossio, J. M. (1999). “Tras la huella de fray Martín de Murúa” ponencia presentada en Perú Hoy. Primer Congreso Internacional de Peruanistas en el Extranjero. Harvard University. Cambridge, Ma., 29 de abril al $1^{\circ}$ de mayo. Disponible en Internet: https://sites.fas. harvard.edu/ icop/juanossio.html. Consultada el: 10 de diciembre de 2016.

» Ossio, J. M. (2005). Polemizando sobre los escritos del padre Martín de Murúa. Histórica XXIX (1): 163-182.

» Ossio, J. M. (2008). “Murúa’s two manuscripts: a comparison” en Cummins T. y B. Anderson (eds.), The Getty Murúa. Essays on the making of Martín de Murúa's 'Historia General del Piru'. Paul Getty Museum Ms. Ludwig XIII 16: 77-94. Los Angeles, The Getty Research Institute.

" Ossio, J. M. (2018). A propósito del misterioso mercedario Fray Martín de Murua. Colonial Latin American Review 27 (2): 280-289.

»Palacio, E. yJ. Brunet (1977). Los Mercedarios en Bolivia. La Paz, Universidad Mayor de San Andrés-Honorable Alcaldía Municipal de La Paz.

» Paredes, M. R. (1968). Los Siñani. La Paz, Isla.

»Paredes Laos, J. (2018). Un misterio llamado Martín de Murúa. El Comercio. Lima, 2 de enero. Disponible en Internet: https://elcomercio.pe/eldominical/misterio-llamadomartin-murua-noticia-485868 Consultado el: 10 de enero de 2018

»Pease G. Y., F. (1978). Del Tawantinsuyu a la Historia del Perú. Lima, IEP.

»Platt, T.; Bouysse-Cassagne T. y O. Harris (2006). Qaraqara-Charka. Mallku, Inka y Rey en la provincia de Charcas (siglos XV-XVII). Historia antropológica de una confederación aymara. La Paz, IFEA-Plural.

»Presta, A. M. (2010). Undressing the coya and dressing the Indian women. Market economy, clothing, and identities in the colonial Andes, La Plata (Charcas), late sixteenth and early seventeenth centuries. Hispanic American Historical Review 90 (1): 41-74.

»Presta, A. M. (2013). “Los valles mesotérmicos de Chuquisaca entre la fragmentación territorial yampara y la ocupación de los migrantes qaraqara y charka en la temprana colonia" en Presta, A. M. (ed.), Aportes Multidisciplinarios al Estudio de los Colectivos Étnicos Surandinos. Reflexiones sobre Qaraqara-Charka tres años después: 27-59. Lima-La Paz, IFEA-Plural.

» Querejazu Escobari, L. (2010). “Cielo/Infierno/Tentación. La muerte en Caquiaviri” en Memoria del V Encuentro Internacional sobre Barroco, Pamplona, Fundación Visión Cultural/Servicio de Publicaciones de la Universidad de Navarra: 271-278. La Paz, Fundación Visión Cultural. 
»Quesada, J. I. (2006). Paseo Genealógico por la Argentina y Bolivia. Buenos Aires, Centro de Genealogía de Entre Ríos.

»Ramos, G. (1993). "Política eclesiástica y extirpación de idolatrías: discursos y silencios en torno al Taqui Onqoy” en Ramos, G. y H. Urbano (comps.), Catolicismo y Extirpación de Idolatrías. Siglos XVI-XVIII, Charcas, Chile, México, Perú: 137-168. Cusco, Centro Bartolomé de las Casas.

» Ramos, G. (2010). Muerte y Conversión en los Andes. Lima y Cuzco, 1532-1670. Lima, IEPIFEA.

» Ramos Gavilán, A. ([1621] 1988). Historia de Nuestra Señora de Copacabana. Lima, Ignacio Prado Pastor.

» Rostworowski, M. (1985-1986). La tasa toledana de Capachica de 1575. Histórica 35: 43-79.

» Rostworowski, M. (2003). Peregrinaciones y procesiones rituales en los Andes. Journal de la Société des Américanistes 89 (2): 97-123.

» Saignes, T. (1984). Las etnias de Charcas frente al sistema colonial (Siglo XVII). Ausentismo y fugas en el debate sobre la mano de obra indígena, 1595-1665. Jahrbuch für Geschichte Lateinamerikas XXI: 27-75.

»Saignes, T. (1987a). De la borrachera al retrato: los caciques andinos entre dos legitimidades (Charcas). Revista Andina 5 (1): 130-170.

» Saignes, T. (1987b). “Ayllus, mercado y coacción colonial: el reto de las migraciones internas en Charcas (siglo XVII)" en Harris, O.; Larson, B. y E. Tandeter (comps.), La Participación Indígena en los Mercados Surandinos. Estrategias y reproducción social, siglos $X V I-X X: 111-158$. La Paz, CERES.

» Saignes, T. y C. B. Loza (1984). El pleito entre Bartolomé Qhari, mallku de los lupaqa, y los corregidores de Chucuito (1619-1643). Historia y Cultura 5-6: 29-48 y 183-193.

»Salles-Reese, V. (1997). From Viracocha to the Virgin of Copacabana. Representations of the sacred at lake Titicaca. Austin, University of Texas Press.

» Sánchez Albornoz, N. (1982). Migraciones internas en el Alto Perú. El saldo acumulado en 1645. Historia Boliviana II (1): 1-19.

»Sánchez Albornoz, N. (1983). Migración rural en los Andes. Sipesipe (Cochabamba), 1645. Revista de Historia Económica I (1): 13-36.

»Sierra Martín, M. (2016). ‘Noticias políticas de Indias’ de Pedro Ramírez del Águila: estudio y edición crítica. Tesis de Doctorado, Universidad de Navarra, Pamplona.

"Solodkow, D. (2014). Etnógrafos Coloniales. Alteridad y escritura en la Conquista de América (siglo XVI). Madrid-Frankfurt, Iberoamericana-Vervuert.

»Spurling, G. E. (1992). The Organization of Craft Production in the Inka State: The potters and weavers of Milliraya. Ph.D. Dissertarion. Ann Arbor, Cornell University/ University Microfilm.

»Stern, S. J. (1986). Los Pueblos Indígenas del Perú y el Desafío de la Conquista Española. Huamanga hasta 1640. Madrid, Alianza.

» Stern, S. (1987). "La variedad y ambigüedad de la intervención indígena andina en los mercados coloniales europeos: apuntes metodológicos” en Harris, O.; Larson, B. y E. Tandeter (comps.), La Participación Indígena en los Mercados Surandinos. Estrategias y reproducción social, siglos XVI-XX: 281-312. La Paz, CERES

» Taylor, W. B. ([1996] 1999). Ministros de lo sagrado. Sacerdotes y feligreses en el México del siglo XVIII. Zamora, El Colegio de Michoacán. 
" Thomson, S. (2006). Cuando sólo reinasen los indios. La política aymara en la era de la insurgencia. La Paz, Muela del Diablo-Aruwiyiri.

» van den Berg, H. (2002). Los milagros de la virgen de Copacabana en las obras de los agustinos Alonso Ramos Gavilán (1570-1639) y Antonio de la Calancha (1584-1654). Anuario de la Academia de Historia Eclesiástica 8: 33-68.

» van den Berg, H. (2015). Introducción a Alonso Ramos Gavilán, Historia del Célebre Santuario de Nuestra Señora de Copacabana y sus Milagros, e Invención de la Cruz de Carabuco: 17-64. Sucre, Archivo y Biblioteca Nacionales de Bolivia.

»Zagalsky, P. C. (2014). La mita de Potosí: una imposición colonial invariable en un contexto de múltiples transformaciones (siglos XVI-XVII; Charcas, virreinato del Perú). Chungara 46 (3): 375-395.

»Zanolli, C. E. (2008). Entre la coerción, la oportunidad y la salvación. Las cofradías de indios de San Antonio de Humahuaca. Siglos XVII y XVIII. Andes 19: 345-369. 


\section{Q Anexo documental}

Informe del Licenciado Pedro Vallejo de Velasco. Caquiaviri, 8 de octubre de 1645. (AGN, Buenos Aires, Sala IX, Legajo 20-4-4).

\section{[1r] Padron}

\section{Provincia de Pacages}

\section{Pueblo de Caquiavire}

1645 años Padron que por mandado del Excelentisimo Señor marques de Mancera, virrey de los reynos del Piru, he hecho el Licenciado Pedro Vallejo de Velazco cura deste pueblo de Caquiavire y vicario de la provincia de Pacages en 8 de octubre de 1645 años.

En que para la ynteligencia del orden y costumbre que corre en los yndios desta tierra, y para que se conosca lo poco que pueden obrar los padrones de la tierra fria que llaman puna y lo mucho los de los valles donde estan retirados los mas de los yndios me ha parecido advertir lo siguiente pues oyendo a unos y a otros, y escogiendo lo mas conveniente asiertan mejor en su govierno los superiores.

1. Lo primero en las visitas ordinarias que segun cada año los corregidores estan con distinçion los yndios que ay tributarios, viejos reserbados, sus mugeres y hijos, y los huerfanos, porque en ellas se pone cada qual por su orden; y aunque esten ausentes no mostrando testimonio de que son muertos se les haze cargo a los caciques y pasan por efectibos, y ningun otro padron puede ser mas cierto que el que se haze por las dichas visitas de corregidores, y en ellas no se pueden ocultar de los presentes ningunos porque como ca dia ban a menos y se les dobla la tasa y las mitas de Potosi y ordinarias, unos a otros se descubren y acusan.

2. Lo segundo que como en estas tierras frias que llaman punas cogen pocos frutos y de ordinario carecen de comidas (como se ha visto en estos tres años consecutibos que ni aun la semilla han cogido), o ya por yrlas a buscar, o ya porque se alquilan con españoles para poder pagar sus tasas (porque no tienen / [1v] otros bienes de que balerse) andan los mas casi todo el año fuera, principalmente por las disposiciones de la mita de Potosi que como les obligan a ajustarlas por entero, sin embargo de estar los pueblos tan diminutos, que en el mejor apenas se halla la mitad de gente, en los razonables la tercia parte de su primera fundacion y reparticion, y esta mitad o tercia parte doblan la tasa y mita, y con esto unos en el trabajo della, otros de juntar los faltos (que de ordinario son muchos porque enferman, mueren o se huyen)los principales y mandones en disponer nuevas mitas no estan en sus pueblos sino rara vez y no pudiendo sufrir tanto travajo continuado, y tantas cargas dobladas y aun quatro dobladas vemos cada dia que se ban adonde no puedan ser hallados buscando la libertad, y por esto se retiran adonde ni oyen misa ni se confiesan ni viven como cristianos y asi los pueblos que dan mita a Potosi estan depoblados, y los valles llenos de gente porque en ellos paran los mas, aunque no todos porque muchos se ban a los mayores desiertos y quebradas por no ser vistos; y si los superiores dizen que por que no sacan estos que estan en los 
valles, se responde que el yndio huido no haze asiento en una parte, muda el traje y el nombre, arrimanse al chacarero donde si ba el cacique, o principal a sacarlo vuelve muy bien açotado o apaleado, y con este miedo no vuelven porque los corregidores han menester en su partido a los vezinos del para sus comodidades (que a buscarlas vienen todos) y jamas hallan ayuda en ellos los yndios de otras provincias, demas de que ni pueden saber todo lo que pasa porque las tierras son muy dilatadas, y no hemos de entender que todos los corregidores son malos que quisa alguno abra bueno aunque algunos no los ayamos visto, y los / [2r] yndios que ban por estos ausentes por ladinos que sean, en comun son todos borrachos, y en beber y en la flema con que disponen qualquiera cosa se les pasa el tiempo, hallanse apretados del, porque tienen otras obligaçiones a que acudir y temiendo el castigo que les amenaça de sus corregidores encomenderos y ofiçiales reales se buelben sin obrar cosa de consideraçion sin gente y sin plata porque la cobrada queda bebida y en averias de hurtos que les hazen en tierras agenas que esto es muy ordinario porque mestizos mulatos y otros yndios ladinos saven quando y como lo han de hazer y con esto ni traen plata para si ni para otros.

Hase experimentado que el embiar españoles a reduzir estos yndios es peor porque tirando solo a los salarios que se les señala les quitan lo que tienen aprovechanse en lo que pueden dejan los mas pobres y los obligan a huyr mas lexos, y si se dize que se busquen personas de satifaçion en la apariencia todos lo parecen y en el efecto ninguno ni se halla porque es menester entender la materia y ser fiel y estas dos propriedades juntas puede averlas en uno mas no se pueden hallar dos siendo necesario muchos.

3. Lo tercero que estando por lo menos el tercio de los yndios que tiene cada pueblo en la mita de Potosi y en yr llebando los faltos, otros en buscar comidas, otros traginando con españoles para pagar sus tasas, ay siempre tan pocos en sus pueblos, que aun para el servicio de sus curas y sus tambos faltan, ademas de que ya por abuso que corre, o por tener capaçidad de pastos los que tienen ganados, no viven juntos en las estancias los de cada ayllo, sino divididos, y asi no es posible que ningun padron baia ajustado como Su Excelencia manda y los curas quisieran, y quando se quiera tantear por el padron de confesados / [2v] los que son faltando los mas como esta dicho lo mas del año, ni todos se confiesan en su pueblo ni se baptizan los hijos en el porque los mas andan juntamente con sus mugeres, y esto en principal quando ban a Potosi donde es ordinario dejarlas empeñadas por lo que deven de los gastos que tienen en suplir faltos, y en rescatarlas tardan un año y otro porque han de buscar con que (desdicha que causa lastima y sin remedio alguno) porque los enteradores y asistentes que llevan a su cargo el enterar a $\underline{10}$ y a $\underline{12}$ yndios que cada uno les cuesta $\underline{150}$ pesos y muchos a $\underline{20}$ no tienen otro caudal que la muger (despues de aver concluydo con lo que tienen) y esta empeñan, y destas estan en Potosi un sin numero de ellas, y los que escapan huyendo no vuelben a sus pueblos, porque no los busquen, y aunque en ellos dejen alguna hazienda, considerando es mas lo que deven la dejan y como esta la eredan secretamente los caciques no les pesa dello ni de que sus dueños parescan jamas = Estos tales caciques siendo como son borrachos en general e yncapaces los mas, comen y beben lo que pueden, y quando se hallan empeñados, y acoçados de trabajo y obligaciones son los primeros que se ban, y la opinion comun que corre entre nosotros, de que ningun yndio ausente se les esconde y que todos reconocen y pagan al cacique es muy contraria el dia de oy que si en tiempos pasados tenian algunos yndios sugetos a su mando y ausentes para quedarse con lo que estos pagaban de tasa repartiendola a los que vivian en su pueblo oy no pueden distribuyr tanta carga en tan pocos y se holgaran 
tenerlos presentes por asegurar la hazienda que poseen poca o mucha y no se las vendiesen para el entero de tasas como cada dia se haze porque no puede un corregidor menos pena / [3r] de que lo pagara de su hazienda, de mas de que estando estos ausentes tan divididos en diferentes provincias no pueden verlos los caciques dado caso que a todos los conoçiesen antes con la probreça que oy dia corren en los unos y en los otros vienen a dejar lo uno por lo otro sin perfiçionar obra alguna ni disponerla con que se continua el mal govierno de todo y sin el que tierra dejara de acavarse si bien algunos caciques que tienen govierno conserban sus pueblos pero son muy raros, y finalmente conforme es el cacique asi esta cada puebloa que ayuda grandemente que el cura solo cite la continua redución de faltos como se be en los que cuydan dellas de atajar los empeños que hazen los principales que en ellos es apetitoso a fin de no pagar o de huyrse.

Dizen los superiores que se busquen los mas capaces para hazerles caciques, estos no los ay en todos los pueblos, ni en ningun linage de hombres se conoce el capaz sino con la experiencia por que los mas no son lo que parecen y esto que pudieran tantear en alguna manera los corregidores al primer año que lo son abren los ojos del conocimiento, al segundo los quitan con que siempre es el govierno a çiegas.

4. Lo quarto lo que ayuda a la mejor destruccion de la puna es que muchos yndios que se ban a los valles y a las çiudades, por salir de la obligacion de mitar en Potosi se asientan por yanaconas del rey (porque estos no tienen mas obligaçon que pagar cinco pesos de tasa en cada año) admitenlos facilmente los corregidores y oficiales reales, ya porque entienden dar provecho a $\mathrm{Su}$ Magestad, o ya porque tienen en ellos mas sirvientes, y aunque ay provisiones del govierno, para que constando ser de pueblos de mita se buelban son tantas las circunstançias que piden para la prueva que es raro y aun ninguno el que se saca, y asi una vez asentado por yanacona del rey con la ayuda que / [3v] hallan y que con el favor que les dan unos y otros que cada qual tiene su arrimo (que es el govierno del mundo) quedan los caciques proprietarios de aquellos yndios cançados ya de mal admitidos en sus alegaciones y pruebas los dejan porque a todos los hallan por contrarios, y aunque lleban exortatorios de sus corregidores, con una epicheya y otra los desbanecen y desta calidad ay muchos yndios en los valles y çiudades, con que la evidençia esta clara de que la puna se ha de acabar y despoblar y es mucho de advertir que el sagrado mayor que oy tienen los yndios desaporvechados es el mismo Potosi donde en su fundacion (segun la reparticion del señor don Francisco de Toledo) fueron $\underline{200}$ yndios y no mas y destos ay oy dia de treynta quarenta mil y en los pueblos donde eran a $\underline{1400}$ y a $\underline{1500}$ no ay $\underline{200}$ y es la razon que como en los años floridos yban muchos mas yndios que los señalados a la mita y se quedaban los mas al ynterez de aquellos tiempos fueron olvidando sus pueblos naturales, los hijos acomodandose a oficios, y mercancias y haziendose esto ya costumbre y mudando en los baptizmos a sus hijos la naturaleza y apellidos proprios se fueron desviando de las obligaciones que tenian sus pasados, $y$ se han quedado libres de todo; $Y$ como la mita de los mineros de Potosi es solo allevar siempre gente de la puna sin atender jamas al desahogo dellos (por los contratos e yntereses que luego referire) se han venido a destruyr los pueblos de donde penden las labores quintos y demas provechos que con el buen govierno y menos crueldad en Potosi estuviera mas asegurado porque con las exorbitançias tan terribles que / [4r] efectos se pueden esperar sino los que se ven de perdicion manifiesta contra pobres yndefensos. 
5. Lo quinto en la fundacion de Potosi se acostumbro a dar a cada yndio una tarea en la saca de los metales (costumbre ordinaria en los minerales) esta se continuo sin moderarla y quando en 20 y en $\underline{30}$ estados de mina les daban tantos montones oy en $\underline{150}$ y en mas estados les dan la misma ya sucede entrar un yndio con uno y dos ayudantes y no poderla cumplir, y la pagan quando el dinero les falta en palos y açotes de suerte que temen ya tanto el yr a la mita por las crueldades que en ellos usan que por escusarse dellas y de los travajos tan doblados que se matan cada dia con ponçoñas que beben y aun conpunalada que se dan tienen aquella tarea por ynfalible con que ni se atreven a quejar al corregidor de la villa ni quando se quejan hallan remedio, porque en aquella confusion de voces en los mineros que solo miran a su comodidades, y en aquel desorden en las repartiçiones de yndios ni ay juizio que baste, ni mandatos que se guarde sino el que es contra el yndio. Y pasa ya por asentado y sino liçito consentido o acostumbrado yndios convertidos en dineros que llaman de faltriquera que aunque ya es muy comun y muy savido oy que son pues 7 pesos que en cada semana paga cada yndio al minero, el descarte de recevirlos es que con ellos alquilan otro en lugar del que los da porque quiere redimir el trabajo pero pregunto si el dar estos yndios es para que saquen provecho y se les deve dar de cada dia qua / [4v] tro reales como dejan estos quatro y dan otros ocho que son doze reales por cada dia por no travajar quando en sus mesmos pueblos buscan con quien arrendarse por menos de dos reales que son 6 pesos en cada mes? Y como estos mineros alquilan como dizen en un peso el yndio de Potosi en lugar del que ba de aca siendo los yndios todos unos en la cudicia, miseria y costumbres y dado caso que fuese asi porque han de tener estos yndios sin poner nada de su casa de balde teniendo obligaçion de pagar quatro reales a cada uno en cada un dia, sino que el yndio de mita ha de dar todos los 7 pesos, algunos habra que travajen con todos los yndios que le estan señalados y buscaran tambien mas porque todos los abra menester pero los mas no quieren yndios sino siete pesos por cada uno en la semana que con $\underline{20}$ yndios que tiene asegura $\underline{140}$ pesos de renta de que comen y visten y es de manera esta que si les faltaran en el entero vienen de Potosi a cobrar los que entre año no les enteraron cosa es en que deve discurrir mucho pues tiene tantas circunstançias de conciençia, ynjusticia y daños a Su Magestad y a estos vasallos yncapaces que con solo huyrse y no parecer se defienden dejando sus pueblos casas y aun sus mugeres muchas.

6. Lo sexto en años atraçados avia algunos caciques capaces y de caudal y que se vestian y trataban con luzimiento y por aver ydo por capitanes de la mita han quedado (los que parecen que los demas ya se los / [5r] ha tragado la tierra segun falta la memoria dellos) tan desdichados que andan con capas remendadas de diferentes colores (que ya no alcançan mas) porque por lo menos cuesta a cada capitan de quinze a veinte mil pesos la capitania, y oy aviendo menos destos se ha tomado medio en Potosi hazer dos capitanes generales (que cada pueblo ya se save da el suio particular) para que asistiendo el uno ande el otro recogiendo gente que dicho asi suena bien, pero el modo de recogerlos es yr y venir por los yndios que tienen alguna costilla aunque no les toque la mita de aquel año, y entre la sinrazon de llevarlos no ay replica ni aun en los mesmos corregidores porque si los defienden a la primera relacion que hagan de ello y con el cargo que les ymponen de que despacharon yndios poco seguros o que los nombraron de los huidos (porque no tuvieron ni pudieron señalar otros) les vienen unos y otros juezes que los destruyen y viendo su empeño tan cierto en su destruccion callan y procuran pasar su tiempo y no osan ni aun hablar en razon de dezir si es bueno o malo con que no ay yndio seguro en su casa ni en los caminos ni defensa para ellos, porque 
conforme los conocen los dichos capitanes echan redes barrederas procurando ajustar su tiempo y como aquesto se haze con comisiones tan apretadas que traen de la villa de Potosi y con bara alta es çierto que ni aun cantores ni sacristanes dejan en las yglesias, pues si sobre esto habla algo algun cura no les dan menos nombre que traidores a Su Magestad y que contravienen a la justiçia ordinaria y la usurpan y otros mil etcetera.

7. Lo septimo los forasteros son pocos los que ay en la puna por ser tierra ynfructifera y estos son como las golon/ [5v] drinas que se ban donde hallan mejor beranoy ninguno confiesa de donde es, tienen los nombres supuestos porque no aya dellos notiçia, no tienen permanençia çierta, y con qualquiera lebe ocaçion se mudan y quando se quisieran asegurar no se halla traça porque quien se ha de encargar de prender con pies ni es posible, ni sobre que culpa distinguida se les ha de prender ni castigar, ademas de que si huelen alguna diligençia contra ellos en una noche se trasponen donde no los puedan hallar. $=$

En los valles pueden hazer de ellos mas cierta matricula y padron porque para cobrar dellos el peso ensayado tienen cuydado los curas de saber quantos son, y en que partes de su distrito vivien, y en la puna no ay peso ensayado porque demas de ser pocos no paran ni son permanentes por ser (como queda dicho) pocos los frutos que se cogen.

8. Lo octavo con el tiempo se mudan las cosas y asi el juzgar dellas en lo presente es la primera razon del govierno $=$ En los pasados estimaban grandemente en comun el ser caciques los yndios, porque el mandar es apetito e ynclinaçion natural, oy los de los valles y lugares de donde no se mita a Potosi lo pretenden grandemente, y sobre serlo tienen grandes pleytos alegaçiones sobre pertenecerles por erençia de sus pasados y en estas contiendas acuden a las audiençias gastan, y regalan a los que pueden ayudarlos, pero en los pueblos donde dan mita el mas capaz desea no serlo hazen cada dia dejaçion de sus casicasgos y quando muere uno resisten grandemente el ser nombrados por caçiques, y contra su voluntad les hazen admitir el cargo, y es de manera, que es esta una / [6r] de las causas prinçipales de desamparar su tierra y huyrse, porque conocen la destrucçion y travajos que dello les resulta, con que facilmente se deja entender el provecho o el daño que se les sigue $=Y$ si en los tiempos pasados los caciques tenian (como es verdad) usurpada gente de que se aprovechaban y no los ponian en visitas, padrones, ni constaba de libros de baptizmos, oy estan usurpados quedando con el discurso del tiempo libres de los que reconoçian, y por estarlo mas se perdieron y sus decendientes no son ya conocidos que como este desorden no se remedio jamas ni se castigo queda ya el ymposible de juntarlos ni conocerlos porque muriendo aquellos caciques y no constando por padrones ni baptizmos ser aquellos yndios de tal y tal pueblo, con la naturaleza mudada, y con asentarse unos por yanaconas del rey otros de chacareros, otros huyendo de unas partes a otras viviendo bagamundos que destos ay en gran cantidad vinieron a perderse.

9. Lo noveno lo que mas encarga Su Magestad en este reyno es el amparo y aiuda de los yndios (principalmente de aquellos que ban a Potosi atendiendo a los travajos que tienen y molestias que pasan) en continuaçion desto despachan los Excelentisimos Señores Virreyes sus provisiones unas y otras en defensa de los yndios, y nada desto lo aprovecha el porque nadie lo save.

Manda Su Magesad por sus reales cedulas que de cada pueblo baya a Potosi la septima parte de los yndios que ubiere, suçedia aver en algunos mas de 
los del numero de su primera reparticion añadioseles esta parte multiplicada pues si en otros la ubo diminuyda como no se les revaja. = Dizen a esto que no porque en los pueblos falte gente se deveentender que esta disipado, y que mientras no lo probaren no se les debe admitir descargo, no ay pueblo en estas provincias que no tenga su provision de diez años a esta parte para que se le haga revisita ninguna / [6v] se haze porque al yndio le falta el estilo, la ayuda la plata, sobrale la yncapacidad, con que no asiertan ni saven ni pueden, diran que cuia es la culpa nadie lo sabe.

Manda el govierno por una provision que asi como se entrega la mita nueva en Potosi, el corregidor de aquella villa entregue la vieja para que se buelba cada uno a su pueblo como tampoco se haze. Dizen a esto que no es posible porque el yndio que acaba su mita se ba a buscar su remedio para desempeñar la muger, el hijo, a llevar comidas a sus pueblos porque salen necesitados causas que parecen justas, pero con que caudal o ganados ban a buscar esto y como si este descargo y otros dados en Potosi quieren que se admitan, no se admiten ninguno de los que dan los yndios, como son los que murieron en el camino, los que enfermaron los que se huyeron, sino que se han de enterar sin que falte dia ni ora sin que se les admita escusa porque el yndio jamas tiene justicia ni razon que le valga.

Estan desta provincia repartidos 24 yndios a particulares para sus particulares servicios que se añadieron en tiempos floridos porque sobraban sin orden del govierno ni ordenança en los quales no tiene Su Magestad servicio ni ynterez, y estos son los primeros que se han de enterar de los que ban de mita que costando cada uno 150 pesos montan $\underline{3600}$ pesos vese claramente que no ay para la mita yndios bastantes ni aun para ajustar la mitad y que se estan destruyendo capitanes asistentes y enteradores, porque no se quitaron estos o con que conciençia los piden estos dueños yntrusos o como lo disimulan los que pueden remediarlo.

Corre asimismo por opinion asentada que el dia de oy ay / [7r] tantos y mas yndios de los que ubo quando la visita general del señor don Francisco de Toledo es asi verdadero pero vease en todos los pueblos y çiudades del reyno que no se hallaron mil yndios por yanaconas del rey que estos eran los que no conocian origen proprio, estos estan en numero, de mas de ochenta mil sin otros que andan bagamundos y perdidos en partes remotas la diminusion del unos causa el aumento de los otros y computados unos con otros en el numero no falta sino a los que dan mita a Potosi y a Guancabelica.

Hemos visto que se han procurado muchos medios de reduzir los pueblos de la punahase hallado (como queda dicho) por experiençia ser de maior daño si no se busca alguno suave y el que seria de maior ymportancia (salvo mejor parecer) es que siendo como son todos basallos de Su Magestad y que la mita de Potosi se ha de continuar (que con esto no ay que hablar palabra) baian a la mita estos yndios yanaconas de Su Magestad pues es en su real serviçio y han tenido y tienen menos carga de tasas que en la septima parte abra bastante numero y aun sobraran y que los de la puna que vemos oy tan disipados que ya estan para asentarse del todo dejen de yr por algun tiempo o por lo menos no baian mas de la septima parte que se hallaren presentes conforme a la cedula real y con este desembaraço ternan lugar los caçiques y prinçipales de hazer sus reduçiones traeran su gente y aun ella misma gozando deste privilegio se verna voluntariamente / $[7 \mathrm{v}]$ porque entender que se pueda de otra manera alentar esta tierra tan cayda y ya tan declarada para sus fines miserables es 
ynposible y es de manera que si no se abrebia con el remedio quedara sin remedio alguno.

\section{Advertencias}

Por las razones atraçadas se verifica no poderse hazer padron con el numero de los yndios presentes por ser tan pocos y asi por declaraçiones de sus mugeres hijos parientes y conocidos con distinsion de cada ayllo que por su camino se facilita se ha venido a sacar los que son efectibos.

De los presentes se dize efectibamente la edad sus mugeres y sus hijos.

De los ausentes se pone fulano tributario porque la edad de unos no la saven otros ni muchas vezes ellos mismos por la yncapacidad que tienen que el referir en cada uno donde esta como y por que seria alargar la relaçion demasiadamente y confundir el tanteo que se deve hazer. Y con estas advertencias se conocera la calidad de cada uno.

En el pueblo de Caquiavire estuvo el numero de los yndios tributarios (de quatro parcialidades que tiene) en mil y quatrocientos y sinquenta yndios que segun las visitas ordinarias de corregidores estan algunos menos de seyscientos / [8r] y entran en estos algunos que aunque no parecen ni ay noticia dellos por no constar de testimonio de que son muertos pasan por efectibos y hazen cargo dellos a los caciques y estos vienen a faltar en este padron con que vienen a ser menos que los que corren por las tales visitas y lo advierto asi porque computados no se atribuya al descuydo ni corta diligençia de mi parte.

Los caciques destas quatro parcialidades que tiene este pueblo son los siguientes

Lauras De la parcialidad de los lauras lo es don Joan Colqueguanca, casado con doña Maria Laymichu.

\section{Hija}

Ana Laymichu de ocho años.

Miracas De la parcialidad de los miracas lo es don Francisco Choquemamani reservado.

\section{Hijo}

Don Diego Chuqui Mamani de quatro años.

Collanas y Chacos De las parcialidades collanas y chacos lo son don Esteban Oliveros y don Antonio Colqueguanca, ambos muy viejos.

Sus hijos estan ya matriculados / [8v] por ser casados y de edad mayor.

\section{Pautas de transcripción}

Se actualizaron las mayúsculas y minúsculas para facilitar la lectura, aunque se mantuvieron los signos de puntuación originales. Las notaciones al margen 
se han señalado con negritas, dejando un espaciado mayor antes de comenzar el texto correspondiente. Las abreviaturas se han desplegado. Se simplificaron las reduplicaciones de letras. Se mantuvo la " $y$ " con el valor vocálico según corresponda. Se conservaron algunas marcas tipográficas propias del amanuense (=). Las aclaraciones y/o agregados se consignaron entre corchetes. 